\title{
Lymphopenia Caused by Virus Infections and the Mechanisms Beyond
}

\author{
Zijing Guo ${ }^{1,2}$, Zhidong Zhang ${ }^{2}$, Meera Prajapati ${ }^{2,3}$ and Yanmin $\mathrm{Li}^{2, *}$ \\ 1 State Key Laboratory on Veterinary Etiological Biology, Lanzhou Veterinary Research Institute, \\ Chinese Academy of Agricultural Sciences, Lanzhou 730030, China; zijingguo7@163.com \\ 2 College of Animal Husbandry and Veterinary Medicine, Southwest Minzu University, \\ Chengdu 610041, China; zhangzhidong@swun.edu.cn (Z.Z.); prajapati_m@hotmail.com (M.P.) \\ 3 National Animal Health Research Centre, Nepal Agricultural Research Council, Lalitpur 44700, Nepal \\ * Correspondence: Drliym@163.com; Tel.: +28-85528276
}

Citation: Guo, Z.; Zhang, Z.; Prajapati, M.; Li, Y. Lymphopenia Caused by Virus Infections and the Mechanisms Beyond. Viruses 2021, 13, 1876. https://doi.org/10.3390/ v13091876

Academic Editor: Ester Ballana Guix

Received: 28 July 2021

Accepted: 18 September 2021

Published: 20 September 2021

Publisher's Note: MDPI stays neutral with regard to jurisdictional claims in published maps and institutional affiliations.

Copyright: (c) 2021 by the authors. Licensee MDPI, Basel, Switzerland. This article is an open access article distributed under the terms and conditions of the Creative Commons Attribution (CC BY) license (https:/ / creativecommons.org/licenses/by/ $4.0 /)$.

\begin{abstract}
Viral infections can give rise to a systemic decrease in the total number of lymphocytes in the blood, referred to as lymphopenia. Lymphopenia may affect the host adaptive immune responses and impact the clinical course of acute viral infections. Detailed knowledge on how viruses induce lymphopenia would provide valuable information into the pathogenesis of viral infections and potential therapeutic targeting. In this review, the current progress of viruses-induced lymphopenia is summarized and the potential mechanisms and factors involved are discussed.
\end{abstract}

Keywords: lymphopenia; viruses; apoptosis; cytokines; immune response

\section{Introduction}

Lymphocytes are important elements of the immune system. They are categorized into T lymphocytes (T cells), B lymphocytes (B cells) and natural killer (NK) cells based on their migration, surface makers and biological functions [1]. Lymphopenia is the condition in which there is an abnormal reduced number of lymphocytes in the peripheral blood. It is diagnosed when a total lymphocyte number is lower than normal for a particular age group (for instance, less than 1000 cells $/ \mu \mathrm{L}$ in older children and adults) [2-4]. Such obvious reduction in blood lymphocytes count occurs due to viral infections [5], chemical and physical lympho-depleting agents [6], autoimmune-related systemic diseases [7], genetic factors [8], cancers [9], sepsis [10] and other severe injuries [11]. Generally, most viruses lead to relative lymphocytosis, while only a few viruses causing severe disease could result in lymphopenia, such as severe acute respiratory syndrome coronavirus-2 (SARS-CoV-2) [12], ebola virus (EBOV) [13] and human immunodeficiency virus (HIV) [14]. Although numerous studies were attempted to reveal the causes of lymphopenia during viral infections, the mechanisms underlying it is still unclear. It is believed that the mechanism underlying lymphocyte depletion is more complicated as different factors or mechanisms are involved during the infection caused by different viruses. In this review, the current progress of the lymphopenia induced by viral infections with emphasis on RNA viruses is summarized and the mechanism and factors involved during various virus infection-mediated lymphopenia are discussed.

\section{Mechanisms of Lymphopenia Associated with Viral Infections}

Lymphopenia was observed in patients and animals infected with different viruses which belong to different viral families and thus exhibit varied morphology, physicochemical and physical properties, genome organization and replication and antigenicity. However, infections by most of these viruses could cause serious illness or even death and it was found that lymphopenia is associated with disease severity. Despite numerous studies on causes of lymphopenia during viral infections, the mechanisms underlying still 
remain vague. The proposed mechanisms for the observed lymphopenia are summarized as follows (Table 1, Figure 1). Unlike the RNA viruses mentioned below, the mechanism of lymphopenia caused by DNA virus infections is also still unknown. So far, the underlying factors and molecular mechanisms of lymphopenia caused by most DNA viruses have rarely been reported which needs to be addressed in the future.

Table 1. Lymphopenia caused by viral infections and the possible mechanisms involved.

\begin{tabular}{|c|c|c|c|c|c|c|}
\hline \multicolumn{2}{|r|}{ Family } & Species & $\begin{array}{l}\text { Lymphocyte } \\
\text { Subsets }\end{array}$ & Percentage Cases & Possible Mechanisms & Reference \\
\hline \multirow{13}{*}{ RNA } & \multirow{6}{*}{ Coronaviridae } & SARS-CoV-2 & $\begin{array}{c}\text { CD8+ T cells, } \\
\text { CD4+ T cells, } \\
\text { B cells, NK cells }\end{array}$ & $\begin{array}{c}85 \% \text { of the severe } \\
\text { COVID- } 19 \\
\text { patients }\end{array}$ & $\begin{array}{c}\text { cell death } \\
\text { cytokines } \\
\text { lymphopoiesis } \\
\text { trafficking } \\
\text { co-inhibitory molecules } \\
\text { metabolic disorders }\end{array}$ & {$[5,14-22]$} \\
\hline & & $\begin{array}{c}\text { Middle east respiratory } \\
\text { syndrome coronavirus } \\
\text { (MERS-CoV) }\end{array}$ & $\mathrm{T}$ cells & $\begin{array}{l}34 \% \text { of the } \\
\text { MERS-CoV } \\
\text { patients }\end{array}$ & $\begin{array}{l}\text { cell death } \\
\text { cytokines } \\
\text { lymphopoiesis } \\
\text { trafficking }\end{array}$ & [23-26] \\
\hline & & $\begin{array}{c}\text { Severe acute respiratory } \\
\text { syndrome coronavirus } \\
\text { (SARS-CoV) }\end{array}$ & $\begin{array}{c}\text { CD4+ T cells, } \\
\text { CD8+ T cells, } \\
\text { B cells, NK cells }\end{array}$ & $\begin{array}{l}90-100 \% \text { patients } \\
\text { in the acute phase } \\
\text { of SARS patients }\end{array}$ & $\begin{array}{l}\text { cell death } \\
\text { cytokines } \\
\text { lymphopoiesis } \\
\text { trafficking } \\
\text { glucocorticoids }\end{array}$ & [27-32] \\
\hline & & $\begin{array}{c}\text { Feline infectious } \\
\text { peritonitis virus (FIPV) }\end{array}$ & $\begin{array}{c}\text { CD4+ T cells, } \\
\text { CD8+ T cells, } \\
\text { B cells, NK cells }\end{array}$ & $\begin{array}{l}77 \% \text { of FIPV } \\
\text { infected-cats }\end{array}$ & $\begin{array}{l}\text { cell death } \\
\text { cytokines }\end{array}$ & [33-36] \\
\hline & & $\begin{array}{l}\text { Canine coronavirus } \\
(\mathrm{CCoV})\end{array}$ & Lymphocytes & unknown & unknown & {$[37]$} \\
\hline & & $\begin{array}{l}\text { Equine coronavirus } \\
(\mathrm{ECoV})\end{array}$ & Lymphocytes & $\begin{array}{l}81 \% \text { of ECoV } \\
\text { infected-horses }\end{array}$ & unknown & {$[38]$} \\
\hline & \multirow{3}{*}{ Retroviridae } & HIV & CD4+ T cells & $\begin{array}{l}49.17-65.2 \% \text { of } \\
\text { AIDS patients }\end{array}$ & $\begin{array}{c}\text { cell death } \\
\text { cytokines } \\
\text { lymphopoiesis } \\
\text { trafficking } \\
\text { co-inhibitory molecules }\end{array}$ & {$[39-47]$} \\
\hline & & $\begin{array}{c}\text { Simian } \\
\text { immunodeficiency virus } \\
\text { (SIV) }\end{array}$ & CD4+ T cells & unknown & $\begin{array}{l}\text { cell death } \\
\text { trafficking }\end{array}$ & [48-50] \\
\hline & & $\begin{array}{l}\text { Bovine leukemia virus } \\
\text { (BLV) }\end{array}$ & B cells & unknown & unknown & {$[51]$} \\
\hline & \multirow{3}{*}{ Filoviridae } & EBOV & $\begin{array}{l}\text { CD4+ T cells, } \\
\text { CD8+ T cells, } \\
\text { NK cells }\end{array}$ & unknown & $\begin{array}{c}\text { cell death } \\
\text { cytokines } \\
\text { trafficking } \\
\text { co-inhibitory molecules }\end{array}$ & {$[13,52-56]$} \\
\hline & & Marburg virus (MARV) & $\begin{array}{l}\text { T cells, B cells, } \\
\text { NK cells }\end{array}$ & unknown & $\begin{array}{c}\text { cytokines } \\
\text { metabolic disorders }\end{array}$ & {$[57-59]$} \\
\hline & & $\begin{array}{l}\text { Bundibugyo virus } \\
\text { (BDBV) }\end{array}$ & Lymphocytes & unknown & cytokines & {$[60]$} \\
\hline & Orthomyxoviridae & $\begin{array}{c}\text { Influenza A virus (IAV), } \\
\text { IAV H5N1 } \\
\text { IAV H7N9 } \\
\text { IAV H1N1 } \\
\text { IAV H5N6 }\end{array}$ & $\begin{array}{c}\text { CD4+ T cells, } \\
\text { CD8+ T cells, } \\
\text { B cells, NK cells }\end{array}$ & unknown & $\begin{array}{c}\text { cell death } \\
\text { cytokines } \\
\text { lymphopoiesis } \\
\text { trafficking } \\
\text { co-inhibitory molecules }\end{array}$ & [61-66] \\
\hline
\end{tabular}


Table 1. Cont

\begin{tabular}{|c|c|c|c|c|c|}
\hline Family & Species & $\begin{array}{l}\text { Lymphocyte } \\
\text { Subsets }\end{array}$ & Percentage Cases & Possible Mechanisms & Reference \\
\hline \multirow{4}{*}{ Paramyxoviridae } & Measles virus (MV) & $\begin{array}{l}\text { CD4+ T cells, } \\
\text { CD8+ T cells, } \\
\text { B cells } \\
\end{array}$ & unknown & $\begin{array}{l}\text { cell death } \\
\text { lymphopoiesis }\end{array}$ & {$[67,68]$} \\
\hline & $\begin{array}{l}\text { Human parainfluenza } \\
\text { virus type } 3 \text { (HPIV3) }\end{array}$ & $\begin{array}{l}\text { CD4+ T cells, } \\
\text { CD8+ T cells, } \\
\text { B cells }\end{array}$ & unknown & unknown & [69] \\
\hline & $\begin{array}{l}\text { Canine distemper virus } \\
\text { (CDV) }\end{array}$ & $\begin{array}{l}\text { CD4+ T cells, } \\
\text { CD8+ T cells, } \\
\text { B cells }\end{array}$ & unknown & $\begin{array}{c}\text { cell death } \\
\text { lymphopoiesis }\end{array}$ & [70-72] \\
\hline & $\begin{array}{c}\text { Peste des petits } \\
\text { ruminants virus (PPRV) }\end{array}$ & Lymphocytes & unknown & unknown & {$[73,74]$} \\
\hline Pneumoviridae & $\begin{array}{l}\text { Respiratory syncytial } \\
\text { virus (RSV) }\end{array}$ & $\begin{array}{l}\text { CD4+ T cells, } \\
\text { CD8+ T cells }\end{array}$ & unknown & $\begin{array}{c}\text { cell death } \\
\text { cytokines } \\
\text { co-inhibitory molecules } \\
\text { metabolic disorders }\end{array}$ & {$[75-78]$} \\
\hline Arteriviridae & $\begin{array}{c}\text { Porcine reproductive } \\
\text { and respiratory } \\
\text { syndrome virus } \\
\text { (PRRSV) }\end{array}$ & T cells, B cells & unknown & $\begin{array}{l}\text { cell death } \\
\text { cytokines } \\
\text { lymphopoiesis }\end{array}$ & {$[79,80]$} \\
\hline \multirow[t]{2}{*}{ Picornaviridae } & $\begin{array}{l}\text { Foot-and-mouth disease } \\
\text { virus (FMDV) }\end{array}$ & $\begin{array}{l}\text { CD4+ T cells, } \\
\text { CD8+ T cells, } \\
\text { B cells }\end{array}$ & unknown & $\begin{array}{l}\text { cell death } \\
\text { cytokines } \\
\text { trafficking }\end{array}$ & [81-85] \\
\hline & $\begin{array}{l}\text { Seneca Valley virus } \\
\text { (SVV) }\end{array}$ & B cells & unknown & cell death & [86] \\
\hline \multirow{6}{*}{ Flaviviridae } & $\begin{array}{l}\text { Classical swine fever } \\
\text { virus (CSFV) }\end{array}$ & $\begin{array}{l}\text { CD4+ T cells, } \\
\text { CD8+ T cells, } \\
\text { B cells }\end{array}$ & unknown & $\begin{array}{c}\text { cell death } \\
\text { cytokines } \\
\text { lymphopoiesis } \\
\text { co-inhibitory molecules }\end{array}$ & [87-90] \\
\hline & Hepatitis C virus (HCV) & $\mathrm{T}$ cells & $\begin{array}{l}6 \% \text { of } \\
\text { HCV-infected } \\
\text { patients with } \\
\text { acute } \\
\text { exacerbation }\end{array}$ & $\begin{array}{c}\text { cell death } \\
\text { co-inhibitory molecules }\end{array}$ & {$[91,92]$} \\
\hline & $\begin{array}{l}\text { Border disease virus } \\
\text { (BDV) }\end{array}$ & Lymphocytes & unknown & unknown & [93] \\
\hline & Dengue Virus (DENV) & Lymphocytes & $\begin{array}{c}91.7 \% \text { of } \\
\text { DENV-infected } \\
\text { patients }\end{array}$ & unknown & [94] \\
\hline & West Nile virus (WNV) & Lymphocytes & unknown & unknown & [95] \\
\hline & $\begin{array}{l}\text { Bovine viral diarrhoea } \\
\text { virus (BVDV) }\end{array}$ & $\begin{array}{l}\text { CD4+ T cells, } \\
\text { CD8+ T cells, }\end{array}$ & unknown & $\begin{array}{c}\text { cell death } \\
\text { lymphopoiesis } \\
\text { co-inhibitory molecules }\end{array}$ & [96] \\
\hline \multirow{3}{*}{ Caliciviridae } & $\begin{array}{c}\text { Human norovirus } \\
(\mathrm{HNoV})\end{array}$ & T cells, B cells & unknown & $\begin{array}{l}\text { cytokines } \\
\text { trafficking }\end{array}$ & {$[97,98]$} \\
\hline & $\begin{array}{l}\text { Rabbit haemorrhagic } \\
\text { disease virus (RHDV) }\end{array}$ & Lymphocytes & unknown & cell death & [99] \\
\hline & Feline calicivirus (FCV) & Lymphocytes & unknown & unknown & {$[100,101]$} \\
\hline Arenaviridae & $\begin{array}{c}\text { Lymphocytic } \\
\text { choriomeningitis virus } \\
\text { (LCMV) }\end{array}$ & T cells, NK cells & unknown & unknown & [102] \\
\hline Togaviridae & $\begin{array}{l}\text { Chikungunya virus } \\
\text { (CHIKV) }\end{array}$ & Lymphocytes & unknown & unknown & [103] \\
\hline
\end{tabular}


Table 1. Cont

\begin{tabular}{|c|c|c|c|c|c|c|}
\hline & Family & Species & $\begin{array}{l}\text { Lymphocyte } \\
\text { Subsets }\end{array}$ & Percentage Cases & Possible Mechanisms & Reference \\
\hline \multirow{7}{*}{ DNA } & Asfarviridae & $\begin{array}{l}\text { African swine fever } \\
\text { virus (ASFV) }\end{array}$ & Lymphocytes & unknown & cell death & [104] \\
\hline & Circoviridae & $\begin{array}{l}\text { Porcine circovirus type } \\
2 \text { (PCV-2) }\end{array}$ & $\begin{array}{c}\text { CD3+CD4+CD8+ } \\
\text { T cells, } \\
\text { CD3+CD4+CD8- } \\
\text { T cells, } \\
\text { CD3+CD4-CD8+ } \\
\text { T cells, } \\
\text { CD3+CD4-CD8- } \\
\text { T cells, B cells, } \\
\text { NK cells }\end{array}$ & unknown & unknown & [105] \\
\hline & \multirow{2}{*}{ Herpesviridae } & $\begin{array}{l}\text { Cytomegalovirus } \\
\text { (CMV) }\end{array}$ & $\begin{array}{l}\text { CD4+ T cells, } \\
\text { CD8+ T cells, } \\
\text { NK cells }\end{array}$ & unknown & unknown & [106] \\
\hline & & $\begin{array}{c}\text { Marek's disease virus } \\
\text { (MDV) }\end{array}$ & B cells & unknown & unknown & {$[107]$} \\
\hline & Alphaherpesvirinae & $\begin{array}{l}\text { Herpes simplex virus } \\
\text { (HSV) }\end{array}$ & Lymphocytes & unknown & unknown & {$[108]$} \\
\hline & \multirow[b]{2}{*}{ Parvoviridae } & Feline parvovirus (FPV) & Lymphocytes & unknown & unknown & [109] \\
\hline & & $\begin{array}{c}\text { Canine parvovirus } \\
\text { (CPV) }\end{array}$ & Lymphocytes & unknown & unknown & {$[110]$} \\
\hline
\end{tabular}

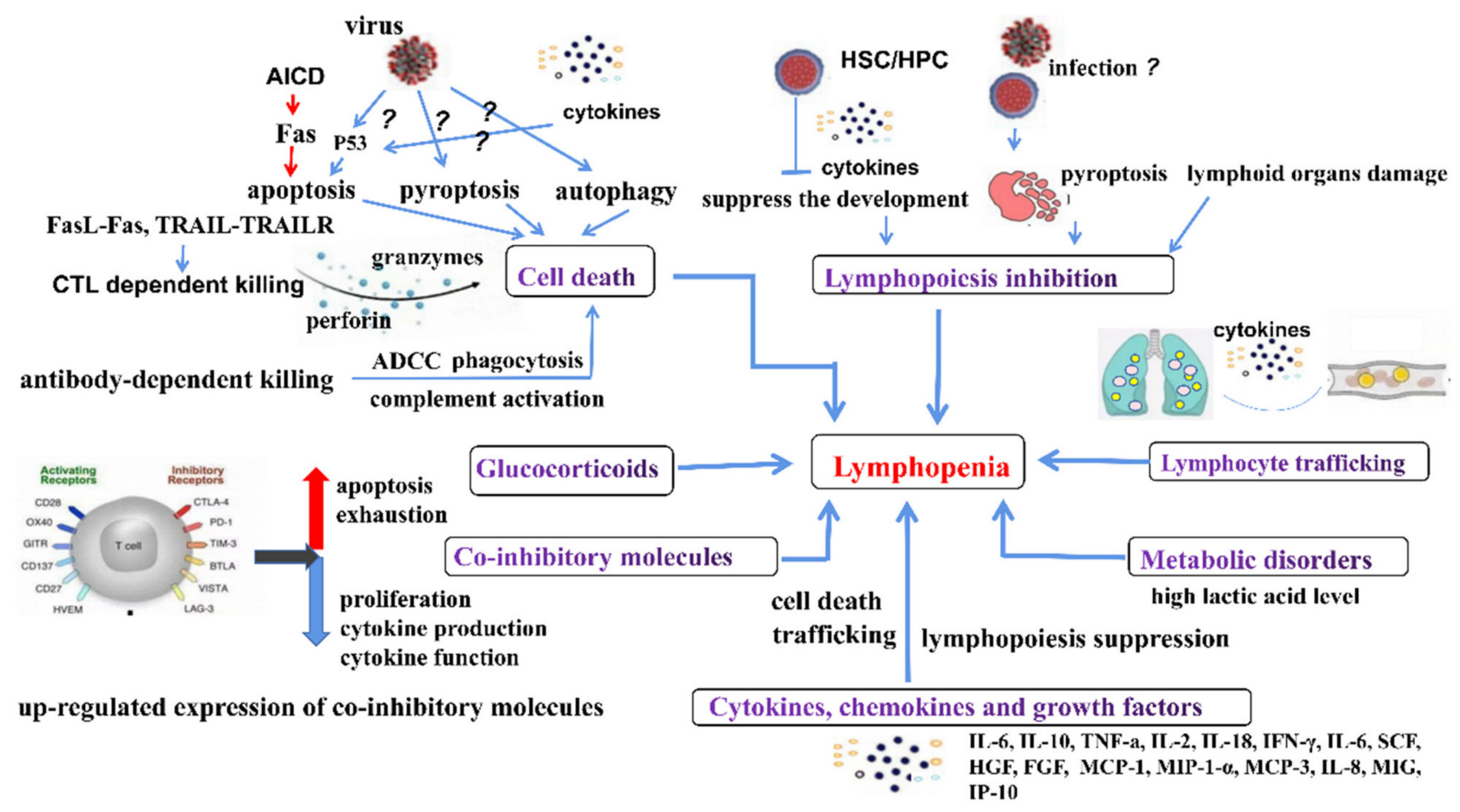

Figure 1. The underlying mechanisms of lymphopenia caused by viral infections.

\subsection{Cell Death}

Lymphocyte death plays a critical role in lymphopenia caused by many viral infections (Table 1). Apoptosis, pyroptosis, autophagy, virus-specific CD8+ cytotoxic T lymphocyte (CTL) dependent killing and antibody-dependent cell-mediated cytotoxicity (ADCC) were reported to be involved in lymphopenia. Among them, apoptosis was thought to be a major pathway involved in lymphopenia $[39,62,68]$.

Apoptosis: Apoptosis is a tightly regulated form of cell death that is vital in both embryo implantation and development and turnover of tissues during maturation. Lympho- 
cyte's apoptosis has been widely reported during viral infections, such as SARS-CoV-2 [15], HIV [39] and IAV [62]. Until now, the mechanism responsible for lymphocytes apoptosis is not fully understood. Although apoptosis of lymphocytes could be induced due to direct infection of lymphocytes with the viruses, such as MERS-CoV [23,24], HIV [111] and MV [67], the number of such virus-infected cells was very few to match with the reduced levels of lymphocytes observed during viral infections. Some studies even suggested that lymphocytes could not be infected by other viruses, such as SARS-CoV-2 [15] and FMDV serotype O/A $[81,84]$. Thus, apoptosis of bystander cells is considered as a major mechanism for lymphocytes depletion induced by viral infections $[39,112,113]$. There were many factors reported to trigger apoptosis in uninfected bystander lymphocytes, including the activation of apoptosis related-receptors (Fas/FasL) [61], the interaction between viral protein and host cellular receptors [114] and cytokines (TNF- $\alpha$ ) $[115,116]$.

Activation-induced cell death (AICD): The interaction between FasL and Fas is usually engaged in AICD, which enhances apoptosis in T lymphocytes previously stimulated to cause contraction of $\mathrm{T}$ cells when $\mathrm{T}$ lymphocytes are re-activated via $\mathrm{T}$ cell receptors (TCR) [117-119]. AICD in peripheral T cells is often caused by the induction of expression of the death ligand, Fas ligand (CD95 ligand, FasL). During SARS-CoV-2-, RSV- and CDVinfection, the Fas expression was negatively correlated to CD4+ T lymphocyte count in blood, indicating that the increased expression of Fas was involved in lymphopenia through apoptosis of bystander T cells $[70,71,76,119]$.

Dendritic cell (DC)-dependent killing of lymphocytes: Previous studies showed that a depletion of CD8+ T cell responses in lethal H2N2 influenza virus infection was mediated by lymph node resident DCs, especially plasmacytoid dendritic cells (pDCs) that express FasL and drive FasL-Fas induced T cell apoptosis in a dose-dependent manner $[120,121]$. Similarly, H5N1 infection in mice enhanced FasL expression on pDCs, resulting in apoptosis of influenza-specific CD8+ T cells via a Fas-FasL-mediated pathway [61,121]. In addition, HIV-infected DCs induced CD8+ T cell apoptosis by up-regulating TNF- $\alpha$ in infected DCs and activation of the caspase 8-dependent pathway in CD8+ T cells [122].

Pyroptosis: Pyroptosis is a programmed cell death with high inflammation. The dying cell releases its cytoplasmic contents, including inflammatory cytokines [123]. These cytokines in turn induce pyroptosis in other $\mathrm{T}$ cells, which also contribute to $\mathrm{T}$ cells depletion. IL-1 $\beta$, a marker of pyroptosis, was increased during SARS-CoV-2 and HIV infection, indicating that lymphocytes were undergoing pyroptosis. During CSFV infection, pyroptosis was also determined in peripheral lymphoid organs by TdT-mediated dUTP nick-end labeling (TUNEL) and detection of pyroptosis related genes (such as p10 subunit, caspase-1 and IL-1 $\beta$ ) [87]. It is necessary to further investigate how these viral infections induce lymphocytes pyroptosis.

Autophagy: Autophagy is an important component of anti-viral defense in host cells. During autophagy, the viruses are initially pinned down into autophagosomes and then delivered to lysosomes for degradation [124]. Until now, autophagy was only reported in patients infected with SARS-CoV-2, HIV and EBOV. In COVID-19 patients, the upregulated expressions of autophagy-associated genes have been observed in PBMCs, which indicates that these cells may undergo autophagy and ultimately cell death [15]. In HIV infected patients, autophagy mediated by HIV gp41 protein was reported in the uninfected CD4+ T cells [41]. In EVD patients, autophagy was induced in T cells through activating endoplasmic reticulum (ER) stress related signaling pathways [13].

Virus-specific CD8+CTL dependent killing: The CTL remove the virus-infected lymphocytes through interaction of FasL with Fas and TNF-related apoptosis-inducing ligand (TRAIL-TRAILR). CTL induce apoptosis of targeted cells by perforin and granzymes and by the death ligand, CD95 ligand (CD95L) [125]. Although a small proportion of lymphocytes infected with SARS-CoV-2 could be eliminated by CTL-dependent killing [126], it is believed that CTLs are not likely to be involved in lymphocytes death due to the lack of infection. Thus, CD8+CTL dependent killing is more likely to occur in lymphocytes infected with MERS-CoV, HIV, CDV, etc. 
ADCC: Antibodies specific to the viral surface antigens are able to block attachment of a virus to its target cell. However, virus-infected cells could be also bound by the antibodies against the virus by recognition of viral antigens presented on the cells. There are a variety of mechanisms involved in killing the antibody-coated cells infected with the virus, such as phagocytosis, activation of complements and ADCC [127]. It is noted that more severe lymphopenia and higher titers of IgG and IgM against the virus were observed in patients, who had severe COVID-19 in comparison with patients having moderate and mild severity [16].

\subsection{Involvement of Cytokines, Chemokines and Growth Factors}

Upregulated expression of cytokines, chemokines and growth factors was commonly observed in patients and animals with lymphopenia induced by viral infection, including IL-2, IL-6, IL-12, IL-18, IL-1 $\beta$, IFN- $\gamma$, CCL2/MCP-1, CXCL1, CXCL8/IL-8, CCL3/MIP-1- $\alpha$, CCL7/MCP-3, CXCL10/IP-10 and CXCL9/MIG $[17,53,128]$. It is noted that the kinds of elevated cytokines, chemokines and growth factors caused by varied viral infections is different, i.e., the infections of SARS-CoV, MERS-CoV, HIV and FMDV could trigger higher levels of IFNs. Conversely, the infection of SARS-CoV-2 did not induce any IFN expression at all assessment time points [129]. Among cytokines, chemokines and growth factors reported, IL-6 is the most common cytokine which was upregulated during infections with many viruses including SARS-CoV-2, SARS-CoV, HIV, EBOV, IAV, RSV, CSFV and HNoV. Different cytokines induced lymphopenia through different mechanisms; it is believed that the synergic action of cytokines, chemokines and growth factors plays a vital role in induction of lymphopenia during viral infection, although the molecular mechanism beyond remains unclear.

IL-6, produced rapidly in response to infection and tissue damage, promotes host defense by stimulating the acute phase responses or immune response. However, the excessive release of IL-6 plays a pathological role in chronic infection and inflammation [130]. Notably, IL-6 could inhibit lymphopoiesis by directly impairing hematopoietic stem cells [131] and STAT-3 activation [132]. Recent studies found that T cells counts were negatively correlated to IL-6, IL-10 and TNF- $\alpha$ concentration in serum, which indicated that these cytokines may be involved in T cells depletion in COVID-19 patients $[18,19]$. The drugs blocking IL-6 receptor (IL-6R), such as tocilizumab, sarilumab and siltuximab, have been considered as a treatment strategy for severe COVID-19 patients with high IL-6 levels [133]. Importantly, lymphocytes count was recovered after treatment with IL-6R [134].

IL-10 as an anti-inflammatory cytokine exhibits a dual role in promoting pathogen persistence [135] and limiting immune pathology [136]. A previous study found that IL-10 was able to suppress proliferation of T cells [137]. Study on chronic infection in animal models showed that blocking IL-10 signaling could successfully prevent T cell exhaustion [138]. In addition, $T$ cell apoptosis could be induced by IL-10 produced by CD9+ regulatory B cells.

TNF- $\alpha$ is also a pro-inflammatory cytokine and could induce cell apoptosis through interacting with its receptor TNFR1 [115]. Previous studies suggested that TNF- $\alpha$ produced by macrophages infected with ASFV leads to apoptosis in bystander T lymphocytes [116]. Similarly, apoptosis was observed earlier in lymphocytes from FIP cats [34], and apoptosis was further reported to be caused by TNF- $\alpha$ or other potential cytokines, instead of viral direct infection $[33,35]$.

Interferons (IFNs) were originally identified as a humoral factor that confer an antiviral state on cells [139], but now, it has also been found to regulate lymphocyte recirculation and cause transient blood lymphopenia [140]. During IAV, CSFV and FMDV infection, the onset of lymphopenia was consistent with the IFN- $\alpha$ responses, and all animals with a high IFN- $\alpha$ level in serum showed severe depletion of lymphocytes $[63,85,88]$. IFN- $\gamma$ has a critical part in bridging the innate and adaptive immunity, but IFN- $\gamma$ has been reported to promote apoptosis. It has been proposed that IFN- $\gamma$ may promote apoptosis of the bystander T cell following EBOV infection [141] 
In addition to IL-6, IL-10, TNF- $\alpha$ and IFNs, other cytokines, chemokines and growth factors were also involved in lymphopenia. For instance, IL-15 has been reported to affect proliferation and differentiation of lymphocytes [142], MCP-1 and CXCL13 were reported to be involved in the migration of lymphocytes $[42,143,144]$.

\subsection{Inhibition of Lymphopoiesis}

There are many ways to inhibit lymphopoiesis during viral infection. First, the damage of lymphoid organs (thymus, lymph nodes, bone marrow, liver and lung) was observed in severe illness caused by SARS-CoV-2, CDV and CSFV with lymphopenia, which has negative impacts on the survival, production and function of lymphocytes [87,89,145-147]. The thymus, an important lymphoid organ, is responsible for the generation and maturation of T cells. However, thymic dysfunction and involution have been observed in patients infected with HIV [148], SARS-CoV-2 [149], MV [150] and H1N1 [151], which were triggered by direct thymocyte killing. Thymus suppression affects lymphopoiesis and the survival of lymphocytes. Second, the development of haematopoietic precursor cells (HPC) was suppressed through viral direct infection and the synergic action of cytokines, chemokines and growth factors. Previous studies postulated that SARS-CoV-2 and CSFV may directly infect haematopoietic stem cells (HSC) and thus induce cell death [20,90]. In addition, hyperproinflammatory cytokines are produced by activated immune cells that affect the process of lymphopoiesis in the bone marrow. Studies have suggested that the reciprocal dynamics of lymphocyte and neutrophil populations in the bone marrow are consistent with cellular interaction and competition [152]. However, inflammation could regulate the balance of granulopoiesis and lymphopoiesis in bone marrow by suppressing common proinflammatory cytokines and growth factors (TNF- $\alpha$, IL-1 $\beta$, CXCL12, IL-6, etc) that affect lymphopoiesis more strongly than granulopoiesis [152,153]. TNF- $\alpha$ treatment results in a reduction in lymphocyte progenitor populations in the bone marrow, while IL-1 $\beta$ elicits increased granulocyte precursors [154]. Moreover, CXCR4-CXCL12 interactions facilitate cytokine-mediated regulation of $\mathrm{B}$ cell and myeloid cell retention in the bone marrow [154]. IL-6 has been reported to abort lymphopoiesis and elevate production of myeloid cells by expression of Id1 transcription factor, which is known to inhibit lymphopoiesis and elevate myelopoiesis, and its expression was dependent on MAPK [131]. Although the cellular source of these cytokines was not determined during many virus infections (e.g., the cellular source of elevated IL-6 in COVID-19 patients [155]), the synergic action of these proinflammatory cytokines may inhibit lymphopoiesis in the bone marrow. Lastly, inhibition of the lymphocyte activation and proliferation by the loss of the antigen-presenting ability would also promote lymphopenia associated with viral infections. For example, DCs from healthy and convalescent COVID-19 patients could stimulate $\mathrm{T}$ cell proliferation, but none of the DCs derived from acute COVID-19 patients showed similar activity, which indicated that DCs from acute patients showed functional impairment in both maturation and T cell activation [21]. Similarly, DCs infected with EBOV and IAV inhibit the ability of antigen presentation and affect the capacity of activating $\mathrm{T}$ cells thereby limiting the ability to pass survival signals to T cells $[54,64,156]$. Further studies revealed that the activation of T cells was inhibited due to steric shielding, in which EBOV GP protein expressed on infected antigen presenting cells (APCs) masks its own epitopes and MHC-I and $\beta 1$ integrin expressed on the cell surface [55]. Furthermore, TCR signal transduction could be inhibited via IFN-inhibiting domains located in viral VP35 and VP24 proteins when EBOV-infected DCs were in contact with T cells [157,158].

\subsection{Lymphocyte Trafficking}

Accumulation of lymphocytes was often observed in infected tissue sites of patients and animals, which was believed to be due to migration from peripheral blood [65,97]. The recovering SARS patients had an average increase of $121 \mathrm{CD} 4+\mathrm{T}$ cells per microliter of peripheral blood during the first month of disease onset; it is speculated that the rapid recovery in lymphocytes blood count is more likely due to the recirculation of lymphocytes 
between organs and peripheral blood, rather than newly produced lymphocytes [28,69]. In addition, various kinds of leucocytes infiltrate the alveoli at various degrees after SARS-CoV-2- and IAV- infections, including lymphocytes, monocytes, neutrophils and eosinophils $[65,159]$. Therefore, lymphocyte sequestration in lungs is considered as a potential pathway for the depletion of blood lymphocytes [160]. Similarly, the loss of circulating lymphocytes temporally coincides with the accumulation of lymphocytes in the lymph nodes and jejunal mucosa following HIV-, SIV- and HNoV-infection, which suggests that lymphopenia may occur as a result of the redistribution of circulating lymphocytes to the infected sites $[50,97,161]$. Although the molecular mechanism for lymphocytes trafficking remains unclear, it seems that CXCL13, IP10 and IFN- $\alpha / \beta$ play an important role in lymphocyte trafficking $[42,44,140]$.

\subsection{Role of Co-Inhibitory Molecules}

$\mathrm{T}$ cell activation requires two signals: TCR stimulation through antigen recognition in the context of MHC and co-stimulation through interaction of co-signaling receptors (co-stimulatory and co-inhibitory receptors) on T cells with their ligands on APCs [162]. Co-signaling receptors play a pivotal role in regulating $\mathrm{T}$ cell activation, subset differentiation, effector function and survival [162]. Co-inhibitory molecules include cytotoxic T-lymphocyte-associated protein 4 (CTLA-4), programmed death 1 (PD-1), T cell immunoreceptor with Ig and ITIM domains (TIGIT), lymphocyte activation gene-3 (LAG-3), T cell immunoglobulin mucin 3 (Tim-3) and 2B4. Up-regulated expression of these co-inhibitory molecules has been reported following viral infection, such as SARS-CoV-2 [22], HIV [45], EBOV [56], IAV [66] and RSV [77]. It is noted that the expression of PD-1, LAG-3 and TIGIT in CD4+ $\mathrm{T}$ cells showed the strongest inverse associations with the number of CD4+ $\mathrm{T}$ cell from AIDS patients [45]. During high-pathological IAV infection, the expression of PD-1 on CD8+ T cells specific for IAV was upregulated, and blockade of PD-L1 in vivo caused reduced titers of virus and increased numbers of CD8+ T cell numbers [66]. PD-1 has been reported to promote $\mathrm{T}$ cells exhaustion and apoptosis and to inhibit proliferation, cytokines production and cytolytic function by regulating signaling of AKT, phosphoinositide 3-kinase (PI3K), extracellular-signal regulated kinase (ERK) and phosphoinositide phospholipase C- $\gamma$ (PLC $\gamma$ ) [163]. A recent study demonstrated that PD-1-mediated $\mathrm{PI} 3 \mathrm{~K} / \mathrm{Akt} / \mathrm{mTOR}$, caspase9/caspase3 and ERK pathways are involved in regulating the apoptosis and proliferation of CD4+ and CD8+ T cells during BVDV infection. The molecular mechanism of other co-inhibitory molecules in lymphopenia caused by viral infection needs further study.

\subsection{Metabolic Disorders}

Lactic acid environments in tumors have been confirmed to suppress the proliferation and cytokines production of human CTLs and lead to a 50\% decrease in cytotoxic activity, and the CTLs function can be restored in a lactic acid-free medium [164]. The level of lactic acid was significantly upregulated in severe COVID-19 patients compared to mild patients [165]. It is speculated that the elevated blood lactic acid levels in severe COVID-19 patients might suppress the proliferation of lymphocytes. In addition, the bilirubin levels (the marker of liver damage), urea nitrogen and creatinine (the markers of renal function) were significantly increased in severe COVID-19 patients $[5,166,167]$. The damage of these organs, especially liver and kidney, may affect the survival, production and function of lymphocytes. Similarly, RSV infected patients who required ICU showed a higher level of prolactin and growth hormone, while the leptin and insulin-like growth factor 1 (IGF1) were obviously decreased [78]. Further analysis revealed that the levels of prolactin and leptin were related to lymphocyte counts, which were considered as potential factors related to lymphopenia in severe RSV infection [78]. Overall, metabolic disorders might shift the normal physiological condition into a pathophysiological situation that may affect the production, survival and function of lymphocytes. 


\subsection{Glucocorticoids}

Glucocorticoids not only exhibit anti-inflammatory actions but also trigger lymphocytes apoptosis that further contributes to lymphopenia $[168,169]$. Previous studies suggested that lymphopenia was more prevalent in SARS patients with higher prevailing cortisol, before any steroid therapy had been used [170]. Similarly, the blood cortisol was significantly higher during the active phase than during the convalescent phase after RSVand EBOV-infection [78,171]. These phenomena revealed that glucocorticoids may be involved in lymphopenia. The role of glucocorticoids in lymphopenia has been reviewed by Panesar N.S. [31]. A recent review study described that the ordering between lymphopenia and lymphocytes apoptosis appears different in SARS and COVID-19 patients (apoptosis is prior to lymphopenia in COVID-19 patients), and the level of glucocorticoids could determine the ordering between lymphopenia [32]. Therefore, glucocorticoids appear to play an important role in lymphopenia caused by virus infections, and glucocorticoids as a drug should be used carefully for treatment in patients with lymphopenia.

\section{Clinical Implications of Lymphopenia during Viral Infections}

\subsection{Association of Lymphopenia with Viral Disease Severity}

Several studies have shown that severe and critically ill individuals during viral infection (such as SARS-CoV-2 or EBOV or AIV), who required intensive care unit (ICU), had obviously lower lymphocyte counts compared to those in healthy, mild or recovered individuals [13,172-174]. This phenomenon indicated that the degree of lymphocyte count has been associated with disease severity [174-176]. T cells play a critical role in virusspecific, adaptive immune response, thereby suggesting that lymphopenia could severely impair the body's ability to fight infection. Likewise, $\mathrm{Xu}$ et al. also pointed out that SARS-CoV-2 leads to lymphocyte depletion and inhibits immune function, which is a potential immunological mechanism for the occurrence and progression of COVID-19 [177]. Moreover, lymphocyte counts in blood is also a viable and accurate index to classify the severity (moderate, severe and critical) of COVID-19 patients [12]. Therefore, lymphopenia could be a clinical indicator for ranking the severity of COVID-19 patients. Similarly, following infections of FIPV [178] and RHDV [179], lymphopenia is also related to the severity of disease. A previous study indicated that lymphopenia was related to disease severity in FIPV infection, and the absolute count of lymphocytes in peripheral blood was recognized as the predictor of the disease outcome [178]. In addition, severe lymphocytes depletion was observed in rabbits infected with RHDV, especially at $6 \mathrm{~h}$ before death of the infected rabbits [99]. Although it is not clear whether lymphopenia promotes the progression of the disease or the severe disease contributes to lymphopenia, it determines that lymphopenia is associated with the severity of the disease. Lymphopenia also can be served as an important indicator for dynamic assessment of disease status.

\subsection{Increases in Opportunistic Infection}

Patients with immunosuppressive conditions are prone to have opportunistic infection, which could be either severe or more frequent. Opportunistic infection is a significant feature during the HIV infection, which could result in high morbidity and even mortality $[180,181]$. Lymphopenia is likely to delay viral clearance, in favor of macrophage stimulation and the accompanying "cytokine storm", which results in the dysfunction of host organs [14,182]. These damages could increase the risk of developing opportunistic infections. A report described that lymphopenia in COVID-19 patients could increase the risk of developing opportunistic infections of mucormycosis, while the recovery of lymphocytes count could improve the acquired immune response and induce the production of mucorales-specific T cells [183]. To the best of our knowledge, there are few reports of opportunistic infections in specific viral diseases accompanied by lymphopenia. Therefore, further investigations are required to reveal the relationship between opportunistic infection and lymphopenia. 


\section{Conclusions}

Lymphocytes, especially specific T cells, have a critical role in viral clearance. Thus, lymphopenia may affect the host adaptive immune responses and impact the clinical course of acute viral infections. In this review, we found that lymphopenia was often seen in patients and animals infected with viruses that could result in serious illness or even death and it was found that lymphopenia is associated with disease severity. Seven different mechanisms were involved in lymphopenia caused by viral infections, including cell death, elevated cytokines, chemokines and growth factors, inhibition of lymphopoiesis, lymphocyte trafficking, up-regulated expression of co-inhibitory molecules, metabolic disorders and elevated glucocorticoids. As it has been discussed in this review, lymphopenia could be caused by different viral infections through multiple mechanisms mentioned above or depending on a certain mechanism. Although the potential mechanisms have been widely reported, the molecular mechanism of these pathways still remains poorly understood, which needs to be addressed in the future.

Author Contributions: Conceptualization, Z.G. and Y.L.; writing—original draft preparation, Z.G.; writing-review and editing, Z.Z., M.P. and Y.L.; funding acquisition, Z.Z. and Y.L. All authors have read and agreed to the published version of the manuscript.

Funding: This work was supported by Southwest Minzu University Research Startup Fund (125900/ 16011211013) and Gansu Province Science and Technology Planning Project (20YF3WA008).

Institutional Review Board Statement: Not applicable.

Informed Consent Statement: Not applicable.

Data Availability Statement: Not applicable.

Acknowledgments: We would like to acknowledge Shuaiyang Zhao for assistance with Figure 1.

Conflicts of Interest: The authors declare that they have no conflict of interest.

$\begin{array}{ll}\text { Abbreviations } \\ \text { T cells } & \text { T lymphocytes } \\ \text { B cells } & \text { B lymphocytes } \\ \text { NK cells } & \text { Natural killer cells } \\ \text { SARS-CoV-2 } & \text { Severe acute respiratory syndrome coronavirus-2 } \\ \text { EBOV } & \text { Ebola virus } \\ \text { HIV } & \text { Human immunodeficiency virus } \\ \text { MERS-CoV } & \text { Middle east respiratory syndrome coronavirus } \\ \text { SARS-CoV } & \text { Severe acute respiratory syndrome coronavirus } \\ \text { FIPV } & \text { Feline infectious peritonitis virus } \\ \text { CCoV } & \text { Canine coronavirus } \\ \text { ECoV } & \text { Equine coronavirus } \\ \text { SIV } & \text { Simian im-munodeficiency virus } \\ \text { BLV } & \text { Bovine leukemia virus } \\ \text { MARV } & \text { Marburg virus } \\ \text { BDBV } & \text { Bun-dibugyo virus } \\ \text { IAV } & \text { Influenza A virus } \\ \text { MV } & \text { Measles virus } \\ \text { HPIV3 } & \text { Human parainfluenza virus type 3 } \\ \text { CDV } & \text { Canine distemper virus } \\ \text { PPRV } & \text { Peste des petits ruminants virus } \\ \text { RSV } & \text { Respiratory syncytial virus } \\ \text { PRRSV } & \text { Porcine reproductive and respiratory syndrome virus } \\ \text { FMDV } & \text { Foot-and-mouth disease virus } \\ \text { SVV } & \text { Seneca Valley virus } \\ \end{array}$




$\begin{array}{ll}\text { CSFV } & \text { Classical swine fever virus } \\ \text { HCV } & \text { Hepatitis C virus } \\ \text { BDV } & \text { Border disease virus } \\ \text { DENV } & \text { Dengue Virus } \\ \text { WNV } & \text { West Nile virus } \\ \text { BVDV } & \text { Bovine viral diarrhoea virus } \\ \text { HNoV } & \text { Human no-rovirus } \\ \text { RHDV } & \text { Rabbit haemorrhagic disease virus } \\ \text { FCV } & \text { Feline calicivirus } \\ \text { LCMV } & \text { Lymphocytic choriomeningitis virus } \\ \text { CHIKV } & \text { Chikungunya virus } \\ \text { ASFV } & \text { African swine fever virus } \\ \text { PCV-2 } & \text { Porcine circovirus type 2 } \\ \text { CMV } & \text { Cytomegalovirus } \\ \text { MDV } & \text { Marek's disease virus } \\ \text { HSV } & \text { Herpes simplex virus } \\ \text { FPV } & \text { Feline parvovirus } \\ \text { CPV } & \text { Canine parvovirus } \\ \text { CTL } & \text { Cytotoxic T lymphocyte } \\ \text { ADCC } & \text { Antibody-dependent cell-mediated cytotoxicity } \\ \text { AICD } & \text { Activation-induced cell death } \\ \text { TCR } & \text { T cell receptor } \\ \text { DC } & \text { Dendritic cell } \\ \text { pDCs } & \text { Plasmacytoid dendritic cells } \\ \text { TUNEL } & \text { TdT-mediated dUTP nick-end labeling } \\ \text { TRAIL } & \text { TNF-related apoptosis-inducing ligand } \\ \text { CD95L } & \text { CD95 ligand } \\ \text { IFNs } & \text { Interferons } \\ \text { HPC } & \text { Haematopoietic precursor cells } \\ \text { APCs } & \text { Antigen presenting cells } \\ \text { CTLA-4 } & \text { Cytotoxic T-lymphocyte-associated protein } 4 \\ \text { PD-1 } & \text { Programmed death 1 } \\ \text { TIGIT } & \text { T cell immunoreceptor with Ig and ITIM domains } \\ \text { LAG-3 } & \text { Lym-phocyte activation gene-3 } \\ \text { Tim-3 } & \text { T cell immunoglobulin mucin 3 } \\ \text { PI3K } & \text { phosphoinositide 3-kinase } \\ \text { ERK } & \text { Extracellular-signal regulated kinase } \\ \text { PLC } \gamma & \text { Phosphoinositide phospholipase C- } \gamma \\ \text { IGF1 } & \text { Insulin-like growth factor 1 } \\ \text { ICU } & \text { Intensive care unit. } \\ & \end{array}$

\section{References}

1. Ratajczak, W.; Niedźwiedzka-Rystwej, P.; Tokarz-Deptuła, B.; Deptuła, W. Immunological memory cells. Cent. Eur. J. Immunol. 2018, 43, 194-203. [CrossRef]

2. Kim, Y.R.; Kim, S.J.; Jung, H.A.; Kim, S.J.; Kim, W.S.; Lee, H.W.; Eom, H.S.; Jeong, S.H.; Park, J.S.; Cheong, J.-W.; et al. Lymphopenia is an important prognostic factor in peripheral T cell lymphoma (NOS) treated with anthracycline-containing chemotherapy. J. Hematol. Oncol. 2011, 4, 34. [CrossRef]

3. Mitrovic, Z.; Suzumiya, J.; Armitage, J.O.; Au, W.Y.; Coiffier, B.; Holte, H.; Jaffe, E.S.; Monserrat, E.; Rajan, S.K.; Savage, K.J.; et al The prognostic significance of lymphopenia in peripheral T cell and natural killer/T cell lymphomas: A study of 826 cases from the International Peripheral T cell Lymphoma Project. Am. J. Hematol. 2012, 87, 790-794. [CrossRef]

4. Ray-Coquard, I.; Van Glabbeke, M.; Sebban, C.; Le Cesne, A.; Judson, I.; Tredan, O.; Verweij, J.; Biron, P.; Labidi, I.; Guastalla, J.-P.; et al. Lymphopenia as a prognostic factor for overall survival in advanced carcinomas, sarcomas, and lymphomas. Cancer Res. 2009, 69, 5383-5391. [CrossRef]

5. Zhang, J.; Cao, Y.; Tan, G.; Dong, X.; Wang, B.; Lin, J.; Yan, Y.; Liu, G.; Akdis, M.; Akdis, C.A.; et al. Clinical, radiological and laboratory characteristics and risk factors for severity and mortality of 289 hospitalized COVID-19 patients. Allergy 2020, 76 , 533-550. [CrossRef] 
6. $\quad$ Lin, A.J.; Rao, Y.J.; Chin, R.-I.; Campian, J.; Mullen, D.; Thotala, D.; Daly, M.; Gay, H.; Oppelt, P.; Hallahan, D.; et al. Post-operative radiation effects on lymphopenia, neutrophil to lymphocyte ratio, and clinical outcomes in palatine tonsil cancers. Oral Oncol. 2018, 86, 1-7. [CrossRef]

7. Merayo-Chalico, J.; Rajme-López, S.; Barrera-Vargas, A.; Alcocer-Varela, J.; Díaz-Zamudio, M.; Gómez-Martín, D. Lymphopenia and autoimmunity: A double-edged sword. Hum. Immunol. 2016, 77, 921-929. [CrossRef]

8. Puck, J.M. Newborn screening for severe combined immunodeficiency and T cell lymphopenia. Immunol. Rev. 2018, 287, 241-252. [CrossRef]

9. Ménétrier-Caux, C.; Ray-Coquard, I.; Blay, J.-Y.; Caux, C. Lymphopenia in cancer patients and its effects on response to immunotherapy: An opportunity for combination with Cytokines? J. Immunother. Cancer 2019, 7, 85. [CrossRef]

10. Drewry, A.M.; Samra, N.; Skrupky, L.P.; Fuller, B.; Compton, S.M.; Hotchkiss, R.S. Persistent lymphopenia after diagnosis of sepsis predicts mortality. Shock 2014, 42, 383-391. [CrossRef]

11. Girardot, T.; Rimmelé, T.; Venet, F.; Monneret, G. Apoptosis-induced lymphopenia in sepsis and other severe injuries. Apoptosis 2016, 22, 295-305. [CrossRef]

12. Henry, B.; Cheruiyot, I.; Vikse, J.; Mutua, V.; Kipkorir, V.; Benoit, J.; Plebani, M.; Bragazzi, N.; Lippi, G. Lymphopenia and neutrophilia at admission predicts severity and mortality in patients with COVID-19: A meta-analysis. Acta Bio Med. Atenei Parm. 2020, 91, e2020008. [CrossRef]

13. Younan, P.; Santos, R.I.; Ramanathan, P.; Iampietro, M.; Nishida, A.; Dutta, M.; Ammosova, T.; Meyer, M.; Katze, M.G.; Popov, V.L.; et al. Ebola virus-mediated T-lymphocyte depletion is the result of an abortive infection. PLoS Pathog. 2019, 15, e1008068. [CrossRef]

14. Peng, X.; Ouyang, J.; Isnard, S.; Lin, J.; Fombuena, B.; Zhu, B.; Routy, J.-P. Sharing CD4+ T Cell Loss: When COVID-19 and HIV Collide on Immune System. Front. Immunol. 2020, 11, 596631. [CrossRef] [PubMed]

15. Xiong, Y.; Liu, Y.; Cao, L.; Wang, D.; Guo, M.; Jiang, A.; Guo, D.; Hu, W.; Yang, J.; Tang, Z.; et al. Transcriptomic characteristics of bronchoalveolar lavage fluid and peripheral blood mononuclear cells in COVID-19 patients. Emerg. Microbes. Infect. 2020, 9 , 761-770. [CrossRef] [PubMed]

16. Xiao, A.T.; Gao, C.; Zhang, S. Profile of specific antibodies to SARS-CoV-2: The first report. J. Infect. 2020, 81, 147-178. [CrossRef]

17. Xu, Z.-S.; Shu, T.; Kang, L.; Wu, D.; Zhou, X.; Liao, B.-W.; Sun, X.-L.; Zhou, X.; Wang, Y.-Y. Temporal profiling of plasma cytokines, chemokines and growth factors from mild, severe and fatal COVID-19 patients. Signal. Transduct. Target. Ther. 2020, 5, 1-3. [CrossRef] [PubMed]

18. Diao, B.; Wang, C.; Tan, Y.; Chen, X.; Liu, Y.; Ning, L.; Chen, L.; Li, M.; Liu, Y.; Wang, G.; et al. Reduction and functional exhaustion of T cells in patients with coronavirus disease 2019 (COVID-19). Front. Immunol. 2020, 11, 827. [CrossRef]

19. Quartuccio, L.; Fabris, M.; Sonaglia, A.; Peghin, M.; Domenis, R.; Cifù, A.; Curcio, F.; Tascini, C. Interleukin 6, soluble interleukin 2 receptor alpha (CD25), monocyte colony-stimulating factor, and hepatocyte growth factor linked with systemic hyperinflammation, innate immunity hyperactivation, and organ damage in COVID-19 pneumonia. Cytokine 2021, 140, 155438. [CrossRef]

20. Ratajczak, M.Z.; Kucia, M. SARS-CoV-2 infection and overactivation of Nlrp3 inflammasome as a trigger of cytokine "storm" and risk factor for damage of hematopoietic stem cells. Leukemia 2020, 34, 1726-1729. [CrossRef]

21. Zhou, R.; To, K.K.; Wong, Y.C.; Liu, L.; Zhou, B.; Li, X.; Huang, H.; Mo, Y.; Luk, T.Y.; Lau, T.T.; et al. Acute SARS-CoV-2 Infection Impairs Dendritic Cell and T Cell Responses. Immunity 2020, 53, 864-877. [CrossRef]

22. Bellesi, S.; Metafuni, E.; Hohaus, S.; Maiolo, E.; Marchionni, F.; D’Innocenzo, S.; La Sorda, M.; Ferraironi, M.; Ramundo, F.; Fantoni, M.; et al. Increased CD95 (Fas) and PD-1 expression in peripheral blood T lymphocytes in COVID-19 patients. Br. J. Haematol. 2020, 191, 207-211. [CrossRef]

23. Liang, Y.; Wang, M.-L.; Chien, C.-S.; Yarmishyn, A.A.; Yang, Y.-P.; Lai, W.-Y.; Luo, Y.-H.; Lin, Y.-T.; Chen, Y.-J.; Chang, P.-C.; et al. Highlight of immune pathogenic response and hematopathologic effect in SARS-CoV, MERS-CoV, and SARS-CoV-2 infection. Front. Immunol. 2020, 11, 1022. [CrossRef]

24. Chu, H.; Zhou, J.; Wong, B.H.-Y.; Li, C.; Chan, J.F.-W.; Cheng, Z.-S.; Yang, D.; Wang, D.; Lee, A.C.Y.; Li, C.; et al. Middle east respiratory syndrome coronavirus efficiently infects human primary $\mathrm{T}$ lymphocytes and activates the extrinsic and intrinsic apoptosis pathways. J. Infect. Dis. 2015, 213, 904-914. [CrossRef]

25. Assiri, A.; Al-Tawfiq, J.A.; Al-Rabeeah, A.A.; Al-Rabiah, F.A.; Al-Hajjar, S.; Al-Barrak, A.; Flemban, H.; Al-Nassir, W.N.; Balkhy, H.H.; Al-Hakeem, R.F.; et al. Epidemiological, demographic, and clinical characteristics of 47 cases of Middle East respiratory syndrome coronavirus disease from Saudi Arabia: A descriptive study. Lancet Infect. Dis. 2013, 13, 752-761. [CrossRef]

26. Leung, C.; Gomersall, C.D. Middle East respiratory syndrome. Intensive Care Med. 2014, 40, 1015-1017. [CrossRef]

27. Wong, C.K.; Lam, C.W.K.; Wu, A.K.L.; Ip, W.K.; Lee, N.; Chan, I.H.S.; Lit, L.C.W.; Hui, D.; Chan, M.H.M.; Chung, S.S.C.; et al. Plasma inflammatory cytokines and chemokines in severe acute respiratory syndrome. Clin. Exp. Immunol. 2004, 136, 95-103. [CrossRef]

28. Li, T.; Qiu, Z.; Zhang, L.; Han, Y.; He, W.; Liu, Z.; Ma, X.; Fan, H.; Lu, W.; Xie, J.; et al. Significant changes of peripheral T lymphocyte subsets in patients with severe acute respiratory syndrome. J. Infect. Dis. 2004, 189, 648-651. [CrossRef]

29. Wong, R.; Wu, A.; To, K.F.; Lee, N.; Lam, C.W.K.; Wong, C.K.; Chan, P.; Ng, M.H.L.; Yu, L.M.; Hui, D.; et al. Haematological manifestations in patients with severe acute respiratory syndrome: Retrospective analysis. BMJ 2003, 326, 1358-1362. [CrossRef] 
30. He, Z.; Zhao, C.; Dong, Q.; Zhuang, H.; Song, S.; Peng, G.; Dwyer, D.E. Effects of severe acute respiratory syndrome (SARS) coronavirus infection on peripheral blood lymphocytes and their subsets. Int. J. Infect. Dis. 2005, 9, 323-330. [CrossRef] [PubMed]

31. Panesar, N. What caused lymphopenia in SARS and how reliable is the lymphokine status in glucocorticoid-treated patients? Med. Hypotheses 2008, 71, 298-301. [CrossRef]

32. Yan, S.; Wu, G. Is lymphopenia different between SARS and COVID-19 patients? FASEB J. 2021, 35, e21245. [CrossRef]

33. Takano, T.; Hohdatsu, T.; Hashida, Y.; Kaneko, Y.; Tanabe, M.; Koyama, H. A “possible” involvement of TNF-alpha in apoptosis induction in peripheral blood lymphocytes of cats with feline infectious peritonitis. Veter. Microbiol. 2007, 119, 121-131. [CrossRef] [PubMed]

34. Haagmans, B.L.; Egberink, H.; Horzinek, M.C. Apoptosis and T cell depletion during feline infectious peritonitis. J. Virol. 1996, 70,8977-8983. [CrossRef]

35. Dean, G.A.; Olivry, T.; Stanton, C.; Pedersen, N.C. In vivo cytokine response to experimental feline infectious peritonitis virus infection. Veter. Microbiol. 2003, 97, 1-12. [CrossRef]

36. Vermeulen, B.L.; Devriendt, B.; Olyslaegers, D.A.; Dedeurwaerder, A.; Desmarets, L.M.; Favoreel, H.; Dewerchin, H.L.; Nauwynck, H.J. Suppression of NK cells and regulatory T lymphocytes in cats naturally infected with feline infectious peritonitis virus. Veter. Microbiol. 2013, 164, 46-59. [CrossRef]

37. Decaro, N.; Elia, G.; Martella, V.; Campolo, M.; Mari, V.; Desario, C.; Lucente, M.S.; Lorusso, E.; Kanellos, T.; Gibbons, R.H.; et al. Immunity after natural exposure to enteric canine coronavirus does not provide complete protection against infection with the new pantropic CB/05 strain. Vaccine 2010, 28, 724-729. [CrossRef]

38. Pusterla, N.; Vin, R.; Leutenegger, C.; Mittel, L.; Divers, T. Enteric coronavirus infection in adult horses. Veter. J. 2017, 231, 13-18. [CrossRef]

39. Garg, H.; Mohl, J.; Joshi, A. HIV-1 Induced Bystander Apoptosis. Viruses 2012, 4, 3020-3043. [CrossRef]

40. Doitsh, G.; Galloway, N.L.K.; Geng, X.; Yang, Z.; Monroe, K.M.; Zepeda, O.; Hunt, P.W.; Hatano, H.; Sowinski, S.; MuñozArias, I.; et al. Cell death by pyroptosis drives CD4 T cell depletion in HIV-1 infection. Nature 2013, 505, 509-514. [CrossRef]

41. Denizot, M.; Varbanov, M.; Espert, L.; Robert-Hebmann, V.; Sagnier, S.; Garcia, E.G.E.; Curriu, M.; Mamoun, R.; Blanco, J.; Biard-Piechaczyk, M. HIV-1 gp41 fusogenic function triggers autophagy in uninfected cells. Autophagy 2008, 4, 998-1008. [CrossRef]

42. Muema, D.; Akilimali, N.A.; Ndumnego, O.; Rasehlo, S.S.; Durgiah, R.; Ojwach, D.B.; Ismail, N.; Dong, M.; Moodley, A.; Dong, K.L.; et al. Association between the cytokine storm, immune cell dynamics, and viral replicative capacity in hyperacute HIV infection. BMC Med. 2020, 18, 1-17. [CrossRef]

43. Palmer, B.E.; Blyveis, N.; Fontenot, A.P.; Wilson, C.C. Functional and phenotypic characterization of CD57+CD4+T cells and their association with HIV-1-induced T cell dysfunction. J. Immunol. 2005, 175, 8415-8423. [CrossRef]

44. Wang, L.; Robb, C.W.; Cloyd, M.W. HIV induces homing of resting T lymphocytes to lymph nodes. Virology 1997, 228, 141-152. [CrossRef]

45. Fromentin, R.; Bakeman, W.; Lawani, M.B.; Khoury, G.; Hartogensis, W.; DaFonseca, S.; Killian, M.; Epling, L.; Hoh, R.; Sinclair, E.; et al. CD4+ T Cells Expressing PD-1, TIGIT and LAG-3 Contribute to HIV persistence during ART. PLoS Pathog. 2016, 12, e1005761. [CrossRef]

46. Bhardwaj, S.; Almaeen, A.; Wani, F.A.; Thirunavukkarasu, A. Hematologic derangements in HIV/AIDS patients and their relationship with the CD4 counts: A cross-sectional study. Int. J. Clin. Exp. Pathol. 2020, 13, 756-763.

47. Parinitha, S.; Kulkarni, M. Haematological changes in HIV infection with correlation to CD4 cell count. Australas. Med. J. 2012, 5, 157-162. [CrossRef]

48. Meythaler, M.; Martinot, A.; Wang, Z.; Pryputniewicz, S.; Kasheta, M.; Ling, B.; Marx, P.A.; O’Neil, S.; Kaur, A. Differential CD4 + T-Lymphocyte apoptosis and bystander T Cell activation in rhesus macaques and sooty mangabeys during acute simian immunodeficiency virus infection. J. Virol. 2009, 83, 572-583. [CrossRef]

49. Iida, T.; Ichimura, H.; Shimada, T.; Ibuki, K.; Ui, M.; Tamaru, K.; Kuwata, T.; Yonehara, S.; Imanishi, J.; Hayami, M. Role of apoptosis induction in both peripheral lymph nodes and thymus in progressive loss of CD4+ cells in shiv-infected macaques. AIDS Res. Hum. Retrovir. 2000, 16, 9-18. [CrossRef]

50. Ponte, R.; Rancez, M.; Figueiredo-Morgado, S.; Dutrieux, J.; Fabre-Mersseman, V.; Charmeteau-De-Muylder, B.; Guilbert, T.; Routy, J.-P.; Cheynier, R.; Couedel-Courteille, A. Acute simian immunodeficiency virus infection triggers early and transient Interleukin-7 production in the gut, leading to enhanced local chemokine expression and intestinal immune cell homing. Front. Immunol. 2017, 8, 588. [CrossRef]

51. Beyer, J.; Kollner, B.; Teifke, J.P.; Starick, E.; Beier, D.; Reimann, I.; Grunwald, U.; Ziller, M. Cattle infected with bovine leukaemia virus may not only develop persistent B cell lymphocytosis but also persistent B cell lymphopenia. J. Veter. Med. Ser. B 2002, 49 , 270-277. [CrossRef]

52. Messaoudi, I.; Amarasinghe, G.K.; Basler, C.F. Filovirus pathogenesis and immune evasion: Insights from Ebola virus and Marburg virus. Nat. Rev. Genet. 2015, 13, 663-676. [CrossRef]

53. McElroy, A.; Erickson, B.R.; Flietstra, T.D.; Rollin, P.; Nichol, S.T.; Towner, J.S.; Spiropoulou, C.F. Ebola hemorrhagic fever: Novel biomarker correlates of clinical outcome. J. Infect. Dis. 2014, 210, 558-566. [CrossRef] 
54. Bosio, C.M.; Grogan, C.; Hogan, R.; Ruthel, G.; Negley, D.; Mohamadzadeh, M.; Bavari, S.; Schmaljohn, A.; Schmaljohn, A. Ebola and Marburg viruses replicate in monocyte-derived dendritic cells without inducing the production of cytokines and full maturation. J. Infect. Dis. 2003, 188, 1630-1638. [CrossRef]

55. Reynard, O.; Borowiak, M.; Volchkova, V.A.; Delpeut, S.; Mateo, M.; Volchkov, V.E. Ebolavirus glycoprotein GP masks both its own epitopes and the presence of cellular surface proteins. J. Virol. 2009, 83, 9596-9601. [CrossRef]

56. Ruibal, P.; Oestereich, L.; Lüdtke, A.; Becker-Ziaja, B.; Wozniak, D.; Kerber, R.; Korva, M.; Cabeza-Cabrerizo, M.; Bore, J.A.; Koundouno, F.R.; et al. Unique human immune signature of Ebola virus disease in Guinea. Nature 2016, 533, 100-104. [CrossRef]

57. Ewers, E.C.; Pratt, W.D.; Twenhafel, N.A.; Shamblin, J.; Donnelly, G.; Esham, H.; Wlazlowski, C.; Johnson, J.C.; Botto, M.; Hensley, L.E.; et al. Natural history of aerosol exposure with marburg virus in rhesus macaques. Viruses 2016, 8, 87. [CrossRef]

58. Fernando, L.; Qiu, X.; Melito, P.L.; Williams, K.J.N.; Feldmann, F.; Feldmann, H.; Jones, S.M.; Alimonti, J.B. Immune response to marburg virus angola infection in nonhuman primates. J. Infect. Dis. 2015, 212, S234-S241. [CrossRef]

59. Geisbert, T.W.; Hensley, L.; Gibb, T.R.; Steele, K.E.; Jaax, N.K.; Jahrling, P.B. Apoptosis induced in vitro and in vivo during infection by ebola and marburg viruses. Lab. Investig. 2000, 80, 171-186. [CrossRef]

60. Kozak, R.; He, S.; Kroeker, A.; de La Vega, M.-A.; Audet, J.; Wong, G.; Urfano, C.; Antonation, K.; Embury-Hyatt, C.; Kobinger, G.P.; et al. Ferrets infected with bundibugyo virus or ebola virus recapitulate important aspects of human filovirus disease. J. Virol. 2016, 90, 9209-9223. [CrossRef]

61. Boonnak, K.; Vogel, L.; Feldmann, F.; Feldmann, H.; Legge, K.L.; Subbarao, K. Lymphopenia associated with highly virulent H5N1 virus infection due to plasmacytoid dendritic Cell-mediated apoptosis of T cells. J. Immunol. 2014, 192, 5906-5912. [CrossRef]

62. Nichols, J.E.; Niles, J.A.; Roberts, N.J. Human lymphocyte apoptosis after exposure to influenza a virus. J. Virol. 2001, 75, 5921-5929. [CrossRef]

63. Gu, Y.; Hsu, A.C.-Y.; Pang, Z.; Pan, H.; Zuo, X.; Wang, G.; Zheng, J.; Wang, F. Role of the innate cytokine storm induced by the influenza a virus. Viral Immunol. 2019, 32, 244-251. [CrossRef]

64. Smed-Sörensen, A.; Chalouni, C.; Chatterjee, B.; Cohn, L.; Blattmann, P.; Nakamura, N.; Delamarre, L.; Mellman, I. Influenza a virus infection of human primary dendritic cells impairs their ability to cross-present antigen to CD8 T cells. PLoS Pathog. 2012, 8, e1002572. [CrossRef]

65. Denney, L.; Aitken, C.; Li, C.K.-F.; Wilson-Davies, E.; Kok, W.L.; Clelland, C.; Rooney, K.; Young, J.D.; Dong, T.; McMichael, A.J.; et al. Reduction of natural killer but Not Effector CD8 T lymphoyctes in three consecutive cases of severe/Lethal H1N1/09 influenza a virus infection. PLoS ONE 2010, 5, e10675. [CrossRef]

66. Rutigliano, J.A.; Sharma, S.; Morris, M.Y.; Oguin, T.H.; McClaren, J.L.; Doherty, P.C.; Thomas, P.G. Highly pathological influenza a virus infection is associated with augmented expression of PD-1 by functionally compromised virus-specific CD8+ T Cells. J. Virol. 2013, 88, 1636-1651. [CrossRef]

67. De Swart, R.L.; Ludlow, M.; De Witte, L.; Yanagi, Y.; Van Amerongen, G.; McQuaid, S.; Yüksel, S.; Geijtenbeek, T.B.H.; Duprex, W.P.; Osterhaus, A. Predominant Infection of CD150+ Lymphocytes and dendritic cells during measles virus infection of macaques. PLoS Pathog. 2007, 3, e178. [CrossRef] [PubMed]

68. Laksono, B.M.; De Vries, R.D.; McQuaid, S.; Duprex, W.P.; De Swart, R.L. Measles virus host invasion and pathogenesis. Viruses 2016, 8, 210. [CrossRef]

69. Gul, A.; Khan, S.; Arshad, M.; Anjum, S.I.; Attaullah, S.; Ali, I.; Rauf, A.; Arshad, A.; Alghanem, S.M.; Khan, S.N. Peripheral blood T cells response in human parainfluenza virus-associated lower respiratory tract infection in children. Saudi J. Biol. Sci. 2020, 27, 2847-2852. [CrossRef]

70. Schobesberger, M.; Summerfield, A.; Doherr, M.; Zurbriggen, A.; Griot, C. Canine distemper virus-induced depletion of uninfected lymphocytes is associated with apoptosis. Veter. Immunol. Immunopathol. 2005, 104, 33-44. [CrossRef]

71. Kajita, M.; Katayama, H.; Murata, T.; Kai, C.; Hori, M.; Ozaki, H. Canine distemper virus induces apoptosis through Caspase-3 and -8 activation in vero cells. J. Veter. Med. Ser. B 2006, 53, 273-277. [CrossRef]

72. Beineke, A.; Puff, C.; Seehusen, F.; Baumgärtner, W. Pathogenesis and immunopathology of systemic and nervous canine distemper. Veter. Immunol. Immunopathol. 2009, 127, 1-18. [CrossRef]

73. Kumar, N.; Maherchandani, S.; Kashyap, S.K.; Singh, S.V.; Sharma, S.; Chaubey, K.K.; Ly, H. Peste Des petits ruminants virus infection of small ruminants: A comprehensive review. Viruses 2014, 6, 2287-2327. [CrossRef]

74. Sharma, C.S.; Mehta, H.K.; Prakash, M.M.; Shukla, P.C. Studies on clinico-haemato-biochemical changes in peste des petits ruminants in goats. Veterinary Practitioner. 2012, 13, 322-325.

75. Russell, C.D.; Unger, S.A.; Walton, M.; Schwarze, J. The human immune response to respiratory syncytial virus infection. Clin. Microbiol. Rev. 2017, 30, 481-502. [CrossRef]

76. Roe, M.F.E.; Bloxham, D.M.; White, D.K.; Ross-Russell, R.I.; Tasker, R.; O'Donnell, D.R. Lymphocyte apoptosis in acute respiratory syncytial virus bronchiolitis. Clin. Exp. Immunol. 2004, 137, 139-145. [CrossRef]

77. Yao, S.; Jiang, L.; Moser, E.; Jewett, L.B.; Wright, J.R.; Du, J.; Zhou, B.; Davis, S.D.; Krupp, N.L.; Braciale, T.J.; et al. Control of pathogenic effector $\mathrm{T}$ cell activities in situ by PD-L1 expression on respiratory inflammatory dendritic cells during respiratory syncytial virus infection. Mucosal Immunol. 2014, 8, 746-759. [CrossRef]

78. Tasker, R.C.; Roe, M.F.E.; Bloxham, D.M.; White, D.K.; Ross-Russell, R.I.; O'Donnell, D.R. The neuroendocrine stress response and severity of acute respiratory syncytial virus bronchiolitis in infancy. Intensiv. Care Med. 2004, 30, 2257-2262. [CrossRef] 
79. Han, J.; Zhou, L.; Ge, X.; Guo, X.; Yang, H. Pathogenesis and control of the Chinese highly pathogenic porcine reproductive and respiratory syndrome virus. Veter. Microbiol. 2017, 209, 30-47. [CrossRef]

80. Canelli, E.; Catella, A.; Borghetti, P.; Ferrari, L.; Ogno, G.; De Angelis, E.; Corradi, A.; Passeri, B.; Bertani, V.; Sandri, G.; et al. Phenotypic characterization of a highly pathogenic Italian porcine reproductive and respiratory syndrome virus (PRRSV) type 1 subtype 1 isolate in experimentally infected pigs. Veter. Microbiol. 2017, 210, 124-133. [CrossRef]

81. Bautista, E.M.; Ferman, G.S.; Golde, W.T. Induction of lymphopenia and inhibition of T cell function during acute infection of swine with foot and mouth disease virus (FMDV). Veter. Immunol. Immunopathol. 2003, 92, 61-73. [CrossRef]

82. Segundo, F.D.-S.; Salguero, F.J.; de Avila, A.; de Marco, M.M.F.; Sánchez-Martín, M.A.; Sevilla, N. Selective lymphocyte depletion during the early stage of the immune response to foot-and-mouth disease virus infection in swine. J. Virol. 2006, 80, 2369-2379. [CrossRef]

83. Joshi, G.; Sharma, R.; Kakker, N.K. Phenotypic and functional characterization of T cells and in vitro replication of FMDV serotypes in bovine lymphocytes. Vaccine 2009, 27, 6656-6661. [CrossRef]

84. Nfon, C.K.; Toka, F.N.; Kenney, M.; Pacheco, J.; Golde, W.T. Loss of plasmacytoid dendritic cell function coincides with lymphopenia and viremia during foot-and-mouth disease virus infection. Viral Immunol. 2010, 23, 29-41. [CrossRef]

85. Eschbaumer, M.; Stenfeldt, C.; Rekant, S.I.; Pacheco, J.M.; Hartwig, E.J.; Smoliga, G.R.; Kenney, M.A.; Golde, W.T.; Rodriguez, L.L.; Arzt, J. Systemic immune response and virus persistence after foot-and-mouth disease virus infection of naïve cattle and cattle vaccinated with a homologous adenovirus-vectored vaccine. BMC Veter. Res. 2016, 12, 205. [CrossRef]

86. De Oliveira, T.E.S.; Leme, R.A.; Agnol, A.M.D.; Gerez, J.R.; Pelaquim, I.F.; Miyabe, F.M.; Alfieri, A.F.; Alfieri, A.A.; Headley, S.A. Seneca valley virus induces immunodepressionin suckling piglets by selective apoptosis of B lymphocytes. Microb. Pathog. 2021, 158, 105022. [CrossRef]

87. Yuan, J.; Zhu, M.; Deng, S.; Fan, S.; Xu, H.; Liao, J.; Li, P.; Zheng, J.; Zhao, M.; Chen, J. Classical swine fever virus induces pyroptosis in the peripheral lymphoid organs of infected pigs. Virus Res. 2018, 250, 37-42. [CrossRef]

88. Summerfield, A.; Alves, M.; Ruggli, N.; De Bruin, M.; McCullough, K. High IFN- $\alpha$ Responses associated with depletion of lymphocytes and natural IFN-Producing cells during classical swine fever. J. Interf. Cytokine Res. 2006, 26, 248-255. [CrossRef]

89. Ma, S.-M.; Mao, Q.; Yi, L.; Zhao, M.-Q.; Chen, J.-D. Apoptosis, autophagy, and pyroptosis: Immune escape strategies for persistent infection and pathogenesis of classical swine fever virus. Pathogens 2019, 8, 239. [CrossRef]

90. Summerfield, A.; Zingle, K.; Inumaru, S.; McCullough, K.C. Induction of apoptosis in bone marrow neutrophil-lineage cells by classical swine fever virus. J. Gen. Virol. 2001, 82, 1309-1318. [CrossRef]

91. Mahale, P.; Kontoyiannis, D.P.; Chemaly, R.F.; Jiang, Y.; Hwang, J.; Davila, M.; Torres, H.A. Acute exacerbation and reactivation of chronic hepatitis C virus infection in cancer patients. J. Hepatol. 2012, 57, 1177-1185. [CrossRef]

92. Aung, A.K.; Robinson, J.; Hey, P.; Lehmann, M.; Chow, Y.; Stark, R.J.; Bosco, J.J. Progressive multifocal leukoencephalopathy secondary to hepatitis C virus infection-related T cell lymphopenia. Intern. Med. J. 2019, 49, 114-118. [CrossRef]

93. Fernández-Sirera, L.; Mentaberre, G.; López-Olvera, J.; Cuenca, R.; Lavín, S.; Marco, I. Haematology and serum chemistry of Pyrenean chamois (Rupicapra pyrenaica) naturally infected with a border disease virus. Res. Veter. Sci. 2011, 90, 463-467. [CrossRef]

94. Le Gonidec, E.; Maquart, M.; Duron, S.; Savini, H.; Cazajous, G.; Vidal, P.-O.; Chenilleau, M.-C.; Roseau, J.-B.; Benois, A.; Déhan, C.; et al. Clinical survey of dengue virus circulation in the Republic of Djibouti between 2011 and 2014 identifies serotype 3 epidemic and recommends clinical diagnosis guidelines for resource limited settings. PLoS Negl. Trop. Dis. 2016, 10, e0004755. [CrossRef]

95. Huhn, G.D.; Sejvar, J.J.; Montgomery, S.P.; Dworkin, M.S. West nile virus in the United States: An update on an emerging infectious disease. Am. Fam. Physician 2003, 68, 653-660.

96. Liu, Y.; Liu, S.; He, B.; Wang, T.; Zhao, S.; Wu, C.; Yue, S.; Zhang, S.; He, M.; Wang, L.; et al. PD-1 blockade inhibits lymphocyte apoptosis and restores proliferation and anti-viral immune functions of lymphocyte after CP and NCP BVDV infection in vitro. Veter. Microbiol. 2018, 226, 74-80. [CrossRef]

97. Dolin, R.; Reichman, R.C.; Fauci, A.S. Lymphocyte populations in acute viral gastroenteritis. Infect. Immun. 1976, 14, 422-428. [CrossRef]

98. Alexander, W.J.; Holmes, J.R.; Shaw, J.F.E.; Riley, W.E.; Roper, W.L. Norwalk virus outbreak at a college campus. South. Med. J. 1986, 79, 33-36. [CrossRef]

99. Ferreira, P.; Costa-E-Silva, A.; Oliveira, M.J.; Monteiro, E.; Cunha, E.; Águas, A.P. Severe leukopenia and liver biochemistry changes in adult rabbits after calicivirus infection. Res. Veter. Sci. 2006, 80, 218-225. [CrossRef]

100. Reubel, G.H.; George, J.W.; Higgins, J.; Pedersen, N.C. Effect of chronic feline immunodeficiency virus infection on experimental feline calicivirus-induced disease. Veter Microbiol. 1994, 39, 335-351. [CrossRef]

101. Terwee, J.; Lauritzen, A.Y.; Sabara, M.; Dreier, K.J.; Kokjohn, K. Comparison of the primary signs induced by experimental exposure to either a pneumotrophic or a 'limping' strain of feline calicivirus. Veter Microbiol. 1997, 56, 33-45. [CrossRef]

102. Rodas, J.D.; Cairo, C.; Djavani, M.; Zapata, J.; Ruckwardt, T.; Bryant, J.; Pauza, C.D.; Lukashevich, I.S.; Salvato, M.S. Circulating natural killer and $\gamma \delta \mathrm{T}$ cells decrease soon after infection of rhesus macaques with lymphocytic choriomeningitis virus. Memórias Do Inst. Oswaldo Cruz 2009, 104, 583-591. [CrossRef]

103. Roques, P.; Thiberville, S.-D.; Dupuis-Maguiraga, L.; Lum, F.-M.; Labadie, K.; Martinon, F.; Gras, G.; Lebon, P.; Ng, L.F.P.; De Lamballerie, X.; et al. Paradoxical effect of chloroquine treatment in enhancing chikungunya virus infection. Viruses 2018, 10, 268. [CrossRef] 
104. Salguero, F.J. Comparative pathology and pathogenesis of African Swine fever infection in Swine. Front. Veter. Sci. 2020, 7, 282. [CrossRef]

105. Nielsen, J.; Vincent, I.; Bøtner, A.; Ladekjær-Mikkelsen, A.-S.; Allan, G.; Summerfield, A.; McCullough, K. Association of lymphopenia with porcine circovirus type 2 induced postweaning multisystemic wasting syndrome (PMWS). Veter. Immunol. Immunopathol. 2003, 92, 97-111. [CrossRef]

106. Qin, L.; Qiu, Z.; Hsieh, E.; Geng, T.; Zhao, J.; Zeng, X.; Wan, L.; Xie, J.; Ramendra, R.; Routy, J.P.; et al. Association between lymphocyte subsets and cytomegalovirus infection status among patients with systemic lupus erythematosus. Medicine 2019, 98, e16997. [CrossRef]

107. Berthault, C.; Larcher, T.; Härtle, S.; Vautherot, J.-F.; Trapp-Fragnet, L.; Denesvre, C. Atrophy of primary lymphoid organs induced by Marek's disease virus during early infection is associated with increased apoptosis, inhibition of cell proliferation and a severe B-lymphopenia. Veter. Res. 2018, 49, 1-18. [CrossRef]

108. Perini, P.; Rinaldi, F.; Puthenparampil, M.; Marcon, M.; Perini, F.; Gallo, P. Herpes simplex virus encephalitis temporally associated with dimethyl fumarate-induced lymphopenia in a multiple sclerosis patient. Mult. Scler. Relat. Disord. 2018, 26, 68-70. [CrossRef]

109. Stuetzer, B.; Hartmann, K. Feline parvovirus infection and associated diseases. Veter. J. 2014, 201, 150-155. [CrossRef]

110. Carman, P.; Povey, R. Pathogenesis of canine parvovirus-2 in dogs: Haematology, serology and virus recovery. Res. Veter. Sci. 1985, 38, 134-140. [CrossRef]

111. Cotton, M.F.; Cassella, C.; Rapaport, E.L.; Tseng, P.O.; Marschner, S.; Finkel, T.H. Apoptosis in HIV-1 infection. Behring Inst. Mitt. 1996, 97, 220-231.

112. Tsao, L.-C.; Guo, H.; Jeffrey, J.; Hoxie, J.A.; Su, L. CCR5 interaction with HIV-1 Env contributes to Env-induced depletion of CD4 T cells in vitro and in vivo. Retrovirology 2016, 13, 22. [CrossRef]

113. Rohwedder, A.; Keminer, O.; Forster, J.; Schneider, K.; Schneider, E.; Werchau, H. Detection of respiratory syncytial virus RNA in blood of neonates by polymerase chain reaction. J. Med. Virol. 1998, 54, 320-327. [CrossRef]

114. Garg, H.; Joshi, A. Host and viral factors in HIV-Mediated bystander apoptosis. Viruses 2017, 9, 237. [CrossRef]

115. Brenner, D.; Blaser, H.; Mak, T.W. Regulation of tumour necrosis factor signalling: Live or let die. Nat. Rev. Immunol. 2015, 15, 362-374. [CrossRef]

116. Del Moral, M.G.; Ortuño, E.; Fernández-Zapatero, P.; Alonso, F.; Alonso, C.; Ezquerra, A.; Domínguez, J. African Swine fever virus infection induces tumor necrosis factor alpha production: Implications in pathogenesis. J. Virol. 1999, 73, 2173-2180. [CrossRef]

117. Sikora, E. Activation-induced and damage-induced cell death in aging human T cells. Mech. Ageing Dev. 2015, 151, 85-92. [CrossRef]

118. Green, D.R.; Droin, N.; Pinkoski, M. Activation-induced cell death in T cells. Immunol. Rev. 2003, 193, 70-81. [CrossRef]

119. Zhu, L.; Yang, P.; Zhao, Y.; Zhuang, Z.; Wang, Z.; Song, R.; Zhang, J.; Liu, C.; Gao, Q.; Xu, Q.; et al. Single-cell sequencing of peripheral mononuclear cells reveals distinct immune response landscapes of COVID-19 and influenza patients. Immunity 2020, 53, 685-696. [CrossRef]

120. Legge, K.L.; Braciale, T.J. Lymph node dendritic cells control CD8+ T cell responses through regulated fasl expression. Immunity 2005, 23, 649-659. [CrossRef]

121. Langlois, R.A.; Legge, K.L. Plasmacytoid dendritic cells enhance mortality during lethal influenza infections by eliminating virus-specific CD8 T cells. J. Immunol. 2010, 184, 4440-4446. [CrossRef]

122. Majumder, B.; Venkatachari, N.J.; Schafer, E.A.; Janket, M.L.; Ayyavoo, V. Dendritic cells infected with vpr -positive human immunodeficiency virus type 1 induce CD8 + T cell apoptosis via upregulation of tumor necrosis factor Alpha. J. Virol. 2007, 81, 7388-7399. [CrossRef]

123. Frank, D.; Vince, J.E. Pyroptosis versus necroptosis: Similarities, differences, and crosstalk. Cell Death Differ. 2018, $26,99-114$. [CrossRef]

124. D'Arcy, M.S. Cell death: A review of the major forms of apoptosis, necrosis and autophagy. Cell Biol. Int. 2019, 43, 582-592. [CrossRef]

125. Barouch, D.H.; Letvin, N.L. CD8+ cytotoxic T lymphocyte responses to lentiviruses and herpesviruses. Curr. Opin. Immunol. 2001, 13, 479-482. [CrossRef]

126. Xu, H.; Zhong, L.; Deng, J.; Peng, J.; Dan, H.; Zeng, X.; Li, T.; Chen, Q. High expression of ACE2 receptor of 2019-nCoV on the epithelial cells of oral mucosa. Int. J. Oral Sci. 2020, 12, 1-5. [CrossRef]

127. Mayr, L.M.; Su, B.; Moog, C. Non-neutralizing antibodies directed against HIV and their functions. Front. Immunol. 2017, 8, 1590. [CrossRef]

128. Wauquier, N.; Becquart, P.; Padilla, C.; Baize, S.; Leroy, E.M. Human fatal zaire ebola virus infection is associated with an aberrant innate immunity and with massive lymphocyte apoptosis. PLoS Negl. Trop. Dis. 2010, 4, e837. [CrossRef]

129. Hadjadj, J.; Yatim, N.; Barnabei, L.; Corneau, A.; Boussier, J.; Smith, N.; Péré, H.; Charbit, B.; Bondet, V.; Chenevier-Gobeaux, C.; et al. Impaired type I interferon activity and inflammatory responses in severe COVID-19 patients. Science 2020, 369, 718-724. [CrossRef]

130. Tanaka, T.; Narazaki, M.; Masuda, K.; Kishimoto, T. Regulation of IL-6 in immunity and diseases. Adv. Exp. Med. Biol. 2016, 941, 79-88. [CrossRef] 
131. Maeda, K.; Malykhin, A.; Teague-Weber, B.N.; Sun, X.-H.; Farris, A.D.; Coggeshall, K.M. Interleukin-6 aborts lymphopoiesis and elevates production of myeloid cells in systemic lupus erythematosus-prone B6.Sle1.Yaa animals. Blood 2009, 113, 4534-4540. [CrossRef]

132. Jenkins, B.J.; Greenhill, C.J.; Najdovska, M.; Lundgren-May, T.; Robb, L.; Grail, D.; Ernst, M.; Ernst, M. Pathologic consequences of STAT3 hyperactivation by IL-6 and IL-11 during hematopoiesis and lymphopoiesis. Blood 2007, 109, 2380-2388. [CrossRef] [PubMed]

133. Palanques-Pastor, T.A.-O.; López-Briz, E.; Poveda Andrés, J.L. Involvement of interleukin 6 in SARS-CoV-2 infection: Siltuximab as a therapeutic option against COVID-19. Eur. J. Hosp. Pharm. 2020, 27, 297-298. [CrossRef]

134. Giamarellos-Bourboulis, E.J.; Netea, M.G.; Rovina, N.; Akinosoglou, K.; Antoniadou, A.; Antonakos, N.; Damoraki, G.; Gkavogianni, T.; Adami, M.-E.; Katsaounou, P.; et al. Complex immune dysregulation in COVID-19 patients with severe respiratory failure. Cell Host Microbe 2020, 27, 992-1000. [CrossRef] [PubMed]

135. Smith, L.K.; Boukhaled, G.M.; Condotta, S.A.; Mazouz, S.; Guthmiller, J.J.; Vijay, R.; Butler, N.; Bruneau, J.; Shoukry, N.H.; Krawczyk, C.M.; et al. Interleukin-10 directly inhibits CD8+ T cell function by enhancing N-Glycan branching to decrease antigen sensitivity. Immunity 2018, 48, 299-312. [CrossRef]

136. De Oca, M.M.; Kumar, R.; Rivera, F.D.L.; Amante, F.H.; Sheel, M.; Faleiro, R.J.; Bunn, P.T.; Best, S.E.; Beattie, L.; Ng, S.; et al. Blimp-1-dependent IL-10 production by Tr1 cells regulates TNF-mediated tissue pathology. PLoS Pathog. 2016, 12, e1005398. [CrossRef]

137. Rojas, J.M.; Avia, M.; Martín, V.; Sevilla, N. IL-10: A multifunctional cytokine in viral infections. J. Immunol. Res. 2017, 2017, 1-14. [CrossRef]

138. Ejrnaes, M.; Filippi, C.M.; Martinic, M.; Ling, E.M.; Togher, L.M.; Crotty, S.; Von Herrath, M.G. Resolution of a chronic viral infection after interleukin-10 receptor blockade. J. Exp. Med. 2006, 203, 2461-2472. [CrossRef] [PubMed]

139. Biron, C.A. Role of early cytokines, including alpha and beta interferons (IFN- $\alpha \backslash \beta$ ), in innate and adaptive immune responses to viral infections. Semin. Immunol. 1998, 10, 383-390. [CrossRef]

140. Kamphuis, E.; Junt, T.; Waibler, Z.; Forster, R.; Kalinke, U. Type I interferons directly regulate lymphocyte recirculation and cause transient blood lymphopenia. Blood 2006, 108, 3253-3261. [CrossRef]

141. Bixler, S.L.; Goff, A.J. The role of cytokines and chemokines in filovirus infection. Viruses 2015, 7, 5489-5507. [CrossRef]

142. Steel, J.; Waldmann, T.A.; Morris, J.C. Interleukin-15 biology and its therapeutic implications in cancer. Trends Pharmacol. Sci. 2012, 33, 35-41. [CrossRef]

143. Deshmane, S.L.; Kremlev, S.; Amini, S.; Sawaya, B.E. Monocyte chemoattractant Protein-1 (MCP-1): An overview. J. Interf. Cytokine Res. 2009, 29, 313-326. [CrossRef]

144. Kazanietz, M.G.; Durando, M.; Cooke, M. CXCL13 and Its Receptor CXCR5 in cancer: Inflammation, immune response, and beyond. Front. Endocrinol. 2019, 10, 471. [CrossRef] [PubMed]

145. Hazenberg, M.D.; Hamann, D.; Schuitemaker, H.; Miedema, F. T cell depletion in HIV-1 infection: How CD4+ T cells go out of stock. Nat. Immunol. 2000, 1, 285-289. [CrossRef]

146. Von Messling, V.; Svitek, N.; Cattaneo, R. Receptor (SLAM [CD150]) recognition and the V protein sustain swift lymphocyte-based invasion of mucosal tissue and lymphatic organs by a morbillivirus. J. Virol. 2006, 80, 6084-6092. [CrossRef]

147. Tan, L.; Wang, Q.; Zhang, D.; Ding, J.; Huang, Q.; Tang, Y.-Q.; Wang, Q.; Miao, H. Lymphopenia predicts disease severity of COVID-19: A descriptive and predictive study. Signal. Transduct. Target. Ther. 2020, 5, 33. [CrossRef]

148. Ye, P.; Kirschner, D.E.; Kourtis, A.P. The thymus during HIV disease: Role in pathogenesis and in immune recovery. Curr. HIV Res. 2004, 2, 177-183. [CrossRef] [PubMed]

149. Lins, M.P.; Smaniotto, S. Potential impact of SARS-CoV-2 infection on the thymus. Can. J. Microbiol. 2021, 67, 23-28. [CrossRef] [PubMed]

150. Ohno, S.; Ono, N.; Seki, F.; Takeda, M.; Kura, S.; Tsuzuki, T.; Yanagi, Y. Measles virus infection of SLAM (CD150) knockin mice reproduces tropism and immunosuppression in human infection. J. Virol. 2007, 81, 1650-1659. [CrossRef] [PubMed]

151. Vogel, A.; Haasbach, E.; Reiling, S.; Droebner, K.; Klingel, K.; Planz, O. Highly pathogenic influenza virus infection of the thymus interferes with T lymphocyte development. J. Immunol. 2010, 185, 4824-4834. [CrossRef] [PubMed]

152. Ueda, Y.; Kondo, M.; Kelsoe, G. Inflammation and the reciprocal production of granulocytes and lymphocytes in bone marrow. J. Exp. Med. 2005, 201, 1771-1780. [CrossRef]

153. Zaretsky, A.G.; Engiles, J.; Hunter, C.A. Infection-induced changes in hematopoiesis. J. Immunol. 2013, 192, 27-33. [CrossRef]

154. Ueda, Y.; Yang, K.; Foster, S.J.; Kondo, M.; Kelsoe, G. Inflammation controls B lymphopoiesis by regulating chemokine CXCL12 expression. J. Exp. Med. 2004, 199, 47-58. [CrossRef] [PubMed]

155. Kahn, R.; Schmidt, T.; Golestani, K.; Mossberg, A.; Gullstrand, B.; Bengtsson, A.A.; Kahn, F. Mismatch between circulating cytokines and spontaneous cytokine production by leukocytes in hyperinflammatory COVID-19. J. Leukoc. Biol. 2020, 109, 115-120. [CrossRef]

156. Mahanty, S.; Hutchinson, K.; Agarwal, S.; McRae, M.; Rollin, P.; Pulendran, B. Cutting edge: Impairment of dendritic cells and adaptive immunity by Ebola and lassa viruses. J. Immunol. 2003, 170, 2797-2801. [CrossRef]

157. Lubaki, N.M.; Ilinykh, P.; Pietzsch, C.; Tigabu, B.; Freiberg, A.N.; Koup, R.A.; Bukreyev, A. The lack of maturation of ebola virus-infected dendritic cells results from the cooperative effect of at least two viral domains. J. Virol. 2013, 87, 7471-7485. [CrossRef] 
158. Lubaki, N.M.; Younan, P.; Santos, R.I.; Meyer, M.; Iampietro, M.; Koup, R.A.; Bukreyev, A. The Ebola interferon inhibiting domains attenuate and dysregulate cell-mediated immune responses. PLoS Pathog. 2016, 12, e1006031. [CrossRef] [PubMed]

159. Yao, X.H.; Li, T.Y.; He, Z.C.; Ping, Y.F.; Liu, H.W.; Yu, S.C.; Mou, H.M.; Wang, L.H.; Zhang, H.R.; Fu, W.J.; et al. A pathological report of three COVID-19 cases by minimally invasive autopsies. Zhonghua Bing Li Xue Za Zhi 2020, 49, 411-417.

160. Jafarzadeh, A.; Jafarzadeh, S.; Nozari, P.; Mokhtari, P.; Nemati, M. Lymphopenia an important immunological abnormality in patients with COVID-19: Possible mechanisms. Scand. J. Immunol. 2020, 93, e12967. [CrossRef]

161. Janossy, G.P.A.; Bofill, M.; Weber, J.; McLaughlin, J.E.; Ornstein, M.; Ivory, K.; Harris, J.R.; Favrot, M.; Macdonald-Burns, D.C. An immunohistological approach to persistent lymphadenopathy and its relevance to AIDS. Clin. Exp. Immunol. 1985, 59, 257-266.

162. Chen, L.; Flies, D.B. Molecular mechanisms of T cell co-stimulation and co-inhibition. Nat. Rev. Immunol. 2013, 13, 227-242. [CrossRef]

163. Jubel, J.M.; Barbati, Z.R.; Burger, C.; Wirtz, D.C.; Schildberg, F.A. The role of PD-1 in acute and chronic infection. Front. Immunol. 2020, 11, 487. [CrossRef]

164. Fischer, K.; Hoffmann, P.; Völkl, S.; Meidenbauer, N.; Ammer, J.; Edinger, M.; Gottfried, E.; Schwarz, S.; Rothe, G.; Hoves, S.; et al. Inhibitory effect of tumor cell-Derived lactic acid on human T cells. Blood 2007, 109, 3812-3819. [CrossRef]

165. Peng, Y.D.; Meng, K.; Guan, H.Q.; Leng, L.; Zhu, R.R.; Wang, B.Y.; He, M.A.; Cheng, L.X.; Huang, K.; Zeng, Q.T. Clinical characteristics and outcomes of 112 cardiovascular disease patients infected by 2019-nCoV. Zhonghua Xin Xue Guan Bing Za Zhi 2020, 48, E004.

166. Paliogiannis, P.; Zinellu, A. Bilirubin levels in patients with mild and severe Covid-19: A pooled analysis. Liver Int. 2020, 40, 1787-1788. [CrossRef]

167. Malik, P.; Patel, U.; Mehta, D.; Patel, N.; Kelkar, R.; Akrmah, M.; Gabrilove, J.L.; Sacks, H. Biomarkers and outcomes of COVID-19 hospitalisations: Systematic review and meta-analysis. BMJ Evid.-Based Med. 2020, 26, 107-108. [CrossRef] [PubMed]

168. Robertson, A.M.G.; Bird, C.C.; Waddell, A.W.; Currie, A.R. Morphological aspects of glucocorticoid-induced cell death in human lymphoblastoid cells. J. Pathol. 1978, 126, 181-187. [CrossRef] [PubMed]

169. Fauci, A.S.; Dale, D.C.; Balow, J.E. Glucocorticosteroid therapy: Mechanisms of action and clinical considerations. Ann. Intern. Med. 1976, 84, 304-315. [CrossRef] [PubMed]

170. Panesar, N.S.; Lam, C.W.K.; Chan, M.H.M.; Wong, C.K.; Sung, J.J.Y. Lymphopenia and neutrophilia in SARS are related to the prevailing serum cortisol. Eur. J. Clin. Investig. 2004, 34, 382-384. [CrossRef]

171. Leroy, E.M.; Baize, S.; Debre, P.; Lansoud-Soukate, J.; Mavoungou, E. Early immune responses accompanying human asymptomatic Ebola infections. Clin. Exp. Immunol. 2001, 124, 453-460. [CrossRef]

172. Lalueza, A.; Folgueira, D.; Díaz-Pedroche, C.; Hernández-Jiménez, P.; Ayuso, B.; Castillo, C.; Laureiro, J.; Trujillo, H.; Torres, M.; Lumbreras, C. Severe lymphopenia in hospitalized patients with influenza virus infection as a marker of a poor outcome. Infect. Dis. 2019, 51, 543-546. [CrossRef]

173. Fathi, N.; Rezaei, N. Lymphopenia in COVID-19: Therapeutic opportunities. Cell Biol. Int. 2020, 44, 1792-1797. [CrossRef]

174. Ruan, Q.; Yang, K.; Wang, W.; Jiang, L.; Song, J. Clinical predictors of mortality due to COVID-19 based on an analysis of data of 150 patients from Wuhan, China. Intensiv. Care Med. 2020, 46, 846-848. [CrossRef]

175. Yang, X.; Yu, Y.; Xu, J.; Shu, H.; Xia, J.; Liu, H.; Wu, Y.; Zhang, L.; Yu, Z.; Fang, M.; et al. Clinical course and outcomes of critically ill patients with SARS-CoV-2 pneumonia in Wuhan, China: A single-lefted, retrospective, observational study. Lancet Respir. Med. 2020, 8, 475-481. [CrossRef]

176. Okur, M.; Erbey, F.; Yazicioglu, O.; Celik, A.; Tukenmez, B.; Sunnetcioglu, M.; Gassaloglu, M.; Acar, M.N.; Kaya, A. H ${ }_{1} N_{1}$ influenza a virus related pneumonia and respiratory failure. Indian J. Virol. 2013, 24, 85-89. [CrossRef]

177. Xu, Z.; Shi, L.; Wang, Y.; Zhang, J.; Huang, L.; Zhang, C.; Liu, S.; Zhao, P.; Liu, H.; Zhu, L.; et al. Pathological findings of COVID-19 associated with acute respiratory distress syndrome. Lancet Respir. Med. 2020, 8, 420-422. [CrossRef]

178. Pedersen, N.C.; Eckstrand, C.; Liu, H.; Leutenegger, C.; Murphy, B. Levels of feline infectious peritonitis virus in blood, effusions, and various tissues and the role of lymphopenia in disease outcome following experimental infection. Veter. Microbiol. 2014, 175, 157-166. [CrossRef]

179. Abrantes, J.; Van Der Loo, W.; Le Pendu, J.; Esteves, P.J. Rabbit haemorrhagic disease (RHD) and rabbit haemorrhagic disease virus (RHDV): A review. Veter. Res. 2012, 43, 12. [CrossRef]

180. Masur, H. Recurring and emerging questions related to management of HIV-related opportunistic infections. Top. Antivir. Med. 2018, 26, 79-84.

181. Ranganathan, K.; Umadevi, K.M.R. Common oral opportunistic infections in Human immunodeficiency virus infection/Acquired Immunodeficiency Syndrome: Changing epidemiology; diagnostic criteria and methods; management protocols. Periodontology 2019, 80, 177-188. [CrossRef] [PubMed]

182. Wang, F.; Hou, H.; Luo, Y.; Tang, G.; Wu, S.; Huang, M.; Liu, W.; Zhu, Y.; Lin, Q.; Mao, L.; et al. The laboratory tests and host immunity of COVID-19 patients with different severity of illness. JCI Insight 2020, 5, e137799. [CrossRef] [PubMed]

183. Pasero, D.; Sanna, S.; Liperi, C.; Piredda, D.; Branca, G.P.; Casadio, L.; Simeo, R.; Buselli, A.; Rizzo, D.; Bussu, F.; et al. A challenging complication following SARS-CoV-2 infection: A case of pulmonary mucormycosis. Infection 2020, 8, 1-6. [CrossRef] 